PIOTR STEFANIAK* - KRAKÓW-BUDAPESZT

\title{
TESTAMENT ŚWIĄTOBLIWEJ OFKI PIASTÓWNY OP, PRZEORYSZY RACIBORSKICH DOMINIKANEK Z 1358 ROKU
}

Spośród średniowiecznych zapisów testamentowych, sporządzonych przez feudalne panie piastowskie na naszą uwagę zasługuje ten, który w sobotę, 8 grudnia 1358 r., w porze nieszporów, kazała sporządzić przeorysza raciborskich dominikanek, Ofka Piastówna (1299-1359). Jest on bowiem interesujący ponieważ dotyczy on mniszki, czyli osoby, która na mocy ślubów zakonnych zobowiązana była do zachowywania ubóstwa partykularnego, ale na mocy urzędu, odpowiadała za pomyślność (w tym ekonomiczną) powierzonej jej wspólnoty zakonnej. Sam testament przygotowany $\mathrm{w}$ dwóch podobnych wersjach był pieczołowicie przechowywany przez dominikanki raciborskie $\mathrm{w}$ archiwum, do momentu kasaty ich klasztoru zarządzonej przez Fryderyka Wilhelma III 30 października 1810 r. ${ }^{1}$ Następnie, wraz z innymi dokumentami, trafił ostatecznie do Archiwum Państwowego we Wrocławiu, gdzie uległ zniszczeniu lub zagrabieniu z końcem II wojny światowej w 1945 r. $^{2}$ Obecnie wrocławskie archiwum posiada 71 dokumentów klasztoru dominikanek w Raciborzu z lat 1295-1809. Szczęśliwie zachowały się dwie edycje tekstu testamentu, który został opublikowany przez Wilhelma Wattenbacha, w wydanym we Wrocławiu w 1892 r. drugim tomie Kodeksu Dyplomatycznego Śląskiego ${ }^{3}$. Zasłużony dla nauki śląski badacz z XIX w. dysponował

* Piotr Stefaniak - mgr historii; współpracownik Domu Polskiego w Budapeszcie; e-mail: piotrmarianstefaniak@gmail.pl

${ }^{1}$ Archiwum Archidiecezjalne we Wrocławiu, sygn. VI B 2a, General-Tableau über sämmtlich eingezogenes Stifts-, Kirchen-, Fundationsvermögen und Ertrag der Stifter und Klöster in Schlesien, k. 6; F. Wolnik, Sekularyzacja raciborskich klasztorów dominikańskich, w: Sekularyzacja dóbr kościelnych na Górnym Śląsku w 1810 roku, red. F. Wolnik, Opole 2011, s. 85.

${ }^{2}$ C. Kwiatkowska, Klasztor Dominikanek w Raciborzu, Rep. 112, w: Archiwum Państwowe we Wroctawiu. Przewodnik po zasobie archiwalnym do 1945 roku, red. A. Dereń, R. Żerelik, Wrocław 1996, s. 291-292.

${ }^{3}$ Codex Diplomaticus Silesiae, wyd. W. Wattenchbach, t. II, Urcunden der Dominikaner und Dominikanerinnen in der Stadt Ratibor, Breslau 1892, s. 156-158 (wersja pierwsza oznaczona cyfrą L) i s. 159-160 (wersja druga oznaczona cyframi LI). 
dwoma czternastowiecznymi pergaminami. Publikując ich treść, jeden oznaczył jako L, a drugi jako LI. Ten ostatni posiadał dwie przytroczone na jedwabnych czerwonych i zielonych niciach pieczęcie. Pierwsza należała do księcia Mikołaja II Przemyślidy i przedstawiała go jako jeźdźca na koniu. Druga, mała i owalna była pieczęcią Ofki Piastówny. Wyobrażała ona jej postać klęczącą przed Najświętszą Maryją Panną z Dzieciątkiem i posiadała napis w otoku: S. SORORIS. OFFCE. ORDIS. PD. ${ }^{4}$ Obie pieczęcie również zaginęły podczas zawieruchy końca II wojny światowej. Pieczęć Ofki jest znana wyłącznie z fotografii, podobnie jak pieczęć konną księcia Mikołaja znamy z przerysu. Była i trzecia pieczęć, signum notariusza publicznego Piotra Gotfridi. Ta jednak była już zaginiona w okresie, gdy miał ją w ręku z końcem XIX w. Wilhelm Wattenbach.

Wspomniany badacz opublikował testament Ofki z 8 grudnia $1358 \mathrm{r}$. oraz wystawiony tego samego dnia instrument notarialny wystawiony przez Piotra, syna Gotfryda z Raciborza i uczynił to w języku oryginału. Teraz zaś zdecydowano się podać jego polski przekład, który w dobie postępującego zaniku znajomości łaciny, spowoduje większą dostępność zawartych w testamencie treści. I choć zamierzenie z punktu widzenia historiografii nie tworzy wartości dodanej - z uwagi na niemożność nowatorskiego odczytania nieistniejącego od czasów II wojny światowej źródła - to jednak z uwagi na wciąż doświadczany deficyt polskich edycji źródeł z terenów Śląska, wydaje się zasadne. W pamięci pozostaje także fakt, że sam Śląski Kodeks Dyplomatyczny nie doczekał się nadal całościowego wydania przez naukę polską, pomimo, że Śląsk od ponad dwóch pokoleń stanowi składową i integralną część współczesnego państwa polskiego. By choć trochę to dotkliwe niedopatrzenie polskich historyków i edytorów, uzupełnić, zdecydowano się zająć jednym ze źródeł śląskich, testamentem Ofki Piastówny i tekst opatrzyć aparaturą naukową. Podjęto się także próby omówienia samego testamentu w kontekście jego znaczenia dla klasztoru raciborskiego oraz tego, czym jest ten dokument dla naszej historiografii.

Nim jednak nastąpi analiza testamentu, zdecydowano się podać w formie skrótowej rys życia jego autorki, świątobliwej Ofki Piastówny ${ }^{5}$, która nie jest zbyt

${ }^{4}$ Sigillum sororis Offce Ordinis Praedicatorum, czyli Pieczęć siostry Ofki z Zakonu Kaznodziejskiego.

${ }^{5}$ G. Kublin, XVII-wieczny żywot księżniczki raciborskiej Eufemii w zbiorach Archiwum Państwowego we Wrocławiu, Opole 2016; H. Kałuża, Korona albo krzyż.., Racibórz 2015; P. Stefaniak, Błogostawione dominikanki; Ofka Piastówna (1299-1359) i Elżbieta Wegierska (1292-1336) środkowoeuropejskie wzorce świętości z XIV wieku, „Studia Teologiczno-Historyczne Śląska Opolskiego" (dalej: STHSO), 35 (2015) s. 292-333; G. Kublin, Niedrukowany dokument z 1 maja 1331 roku dotyczacy klasztoru dominikanek w Raciborzu, STHSO, 35 (2015) s 335-343; P. Stefaniak, Ikonografia światobliwej Ofki Piastówny, Wrocław 2015; G. Kublin, Świątobliwa Eufemia raciborska (†17 I 1359), Opole 2013; P. Stefaniak, Eufemia Domicylla Piastówna, zwana błogosławiona (1299-1359), „List do Pani”, 12/120 (2000) 2012, s. 32; G. Kublin, Eufemia raciborska - priorissa, STHSO, 32: 2012, s. 287-294; tenże, Sprawa zagubienia się pieniędzy Eufemii, STHSO, 30 (2010) s. 493-499; N. Mika, Dzieje ziemi raciborskiej, Kraków 2012, s. 37; Mika, Š. Bělastová, Racibórz-Opava. Podręcznik do edukacji regionalnej. Přriručka k regionální výuce, Racibórz-Opava 2010, s. 94-97; P. Stefaniak, Mistyczki. Święte i błogosławione mniszki dominikańskie, Racibórz 2007, s. 44-48; tenże, Raciborska przeorysza Eufemia Domicylla Piastówna (1299-1359), „Miejsca Świę- 
szeroko znana w kręgach polskich historyków. Była ona córką księcia racibor-

te", 8 (127) 2007; tenże, Dzieje dominikanek raciborskich. Studia na jubileusz 700-lecia fundacji klasztoru Świętego Ducha w Raciborzu i 800-lecia założenia mniszek Zakonu Kaznodziejskiego, Racibórz 2006, s. 18-52, 57-60, 100-109; tenże, Błogostawiona Eufemia Piastówna OP (12991359) w świetle trzech najstarszych żywotów oraz źródeł a także literatury, „Nasza Przeszłość”, 111 (2009) s. 159-191; tenże, Z dziejów relikwii świątobliwej Ofki Piastówny, dominikanki raciborskiej, „Śląskie Studia Historyczno-Teologiczne”, 44 (2011) z. 1, s. 45-58; F. Wolnik, Świątobliwa Eufemia (Ofka) - życie i rozwój jej kultu, w: Świętość na ziemi raciborskiej. Materiały z sesji naukowej zorganizowanej w dniu 16 stycznia 2009 przez Urząd Miejski w Raciborzu, Parafię Wniebowzięcia NMP w Raciborzu oraz Katedrę Historii Kościoła i Patrologii Wydziału Teologicznego Uniwersytetu Opolskiego w Muzeum Miejskim w Raciborzu, z okazji 650. rocznicy śmierci światobliwej Eufemii (Ofki), red. F. Wolnik, Opole 2009, s. 23-43; P. Newerla, Dzieje Raciborza i jego dzielnic, Racibórz 2008, s. 100-102, 122-125; A. Szymański, Świątobliwa Eufemia (Ofka) raciborska-księżna i dominikanka, „Studia Śląskie”, 64 (2005) s. 217-230; G. Wawoczny, Światobliwa Ofka Piastówna, w: Dzieje parafii Wniebowzięcia Najświętszej Maryi Panny w Raciborzu, red. G. Wawoczny, Racibórz 2005, s. 181-194; N. Mika, Eufemia (Ofka), w: Raciborzanie tysiaclecia. Stownik biograficzny, Racibórz 2002, s. 32-33; G. Wawoczny, Miejsca święte ziemi raciborskiej, Racibórz 2001, s. 194207; B. Snoch, Górnośląski leksykon biograficzny, Katowice 1997, s. 51; J. Pater, Święci w dziejach Ślaska, Wrocław 1997, s. 32-34; P. Porwoł, Kaplica św. Dominika (1-2), „Nowiny Raciborskie”, 5 (1996) nr 27-28, s. 8; tenże, Kaplica Polska (1-2), „Nowiny Raciborskie”, 5 (1996) nr 29-30, s. 8; tenże, Zagadkowy obraz świątobliwej Eufemii (1-5), „Nowiny. Tygodnik ziemi rybnickiej, wodzisławskiej i raciborskiej”, 36 (1995) s. 38, 40-42, s. 7; A. Barciak, Eufemia (1299/1301-1359), w: Książęta i księżne Górnego Śląska, red. A. Barciak, Katowice 1995, s. 41-42; S. Madro, Euphemia v. Ratibor, w: Lexikon für Theologie und Kirche, t. 3, Freiburg 1995, szp. 992; J. Mrówczyński, Polscy kandydaci do chwały ołtarzy, Wrocław 1987, s. 185-186; J. Bazydło, Eufemia, Ofka Piastówna, Domicella, w: Encyklopedia katolicka, t. 4, Lublin 1985, kol. 1287-1288; B. Suchoń, Ofka, Eufemia, Domitilla, w: Hagiografia polska. Stownik bio-bibliograficzny, t. 2, red. R. Gustaw, Poznań 1972, s. 160-171; J. Sossalla, Sylwetka świątobliwej Ofki, „Wiadomości Urzędowe Kurii Biskupiej Śląska Opolskiego", 27 (1972) nr 2, s. 57-60; K. Prus, Świątobliwa Ofka Piastówna i klasztor ss. dominikanek w Raciborzu, Opole 1948; J. Woroniecki, Eufemia raciborska, w: Polski stownik biograficzny (dalej: PSB), t. 4, red. W. Konopczyński, Kraków 1948, s. 318-319; J. Gottschalk, Euphemia von Ratibor (†1359). Untersuchung der Quellen zu ihrer Lebensgeschichte, „Archiv für schlesische Kirchengeschichte”, 1 (1936) s. 15-40; P.M. Bazan, Eufemia von Ratibor. Blume aus dem Garten des hl. Dominikus im Rufe der Heiligkeit gestorben am 17. Januar 1359. Ein Lebens- und Zeitbild, Vechta 1936; G. Hyckel, Die gottselige Euphemia von Ratibor, ,Taubstummen-Führer”, 35 (1930) nr 11, s. 77; H. Wilms, Geschichte der deutschen Dominikanerinnen 1206-1916, Dülmen 1920, s. 122-123; H. Ballestrem, Eine Perle des Schlesierlandes, „Deutscher Hausschatz”, 31 (1905) $\mathrm{nr} 22$, s. 704; H. Schaffer, Geschichte einerschlesischen Liebfrauengilde seit dem Jahre 1343. Ein Beitrag zu der Geschichte der Gilden und religiösen Bruderschaften. Nach Urkunden und handschriftlichen Quellen verfaßt, Ratibor 1883, s. 159-174; A. Weltzel, Geschichte der Stadt und Herrschaft Ratibor, Ratibor 1881, s. 814-821, 830; tenże, Żywot Btogostawionej Eufemii, „Towarzystwo Bożego Grobu”, 11 (1878) z. 22, s. 477-492; W. Plebankiewicz, Eufemija Domicella, „Przyjaciel Ludu", 9 (1842) nr 12, s. 95-96; C. Linge, Schulschriften, Breslau 1828, s. 109-122; C. Linge, Denkwürdigkeiten Oberschlesiens, cz. 3. Ratibor 1824, s. 3-10; C. Gromann, Nachrichten über Ratibor, „Allgemeiner Anzeiger des Oberschlesischen Patriotischen Instituts für Landwirthe, Kaufleute, Fabrikanten und Künstler“, 1 (1810) nr 86, s. 454-455. 
skiego Przemysła (1258/1276-1306 ${ }^{6}$ i jego małżonki, księżniczki czerskiej Anny (ok. 1270-1324) ${ }^{7}$. Hagiografia i historiografia przyjęła, że Ofka urodziła się na raciborskim zamku około 1299 r. ${ }^{8}$ Genealodzy wskazują także na lata 1299-13019. Wolą jej ojca było, aby wstąpiła do ufundowanego w Raciborzu przez Przemysła 1 października 1299 r. klasztoru dominikanek. Tak bowiem należy odczytywać wydany 9 kwietnia 1306 r. akt fundacyjny klasztoru dominikanek w Raciborzu, w którym książę zabezpieczył posag swej córki Ofki ${ }^{10}$.

Księżniczka swą formację intelektualną i duchową otrzymała najpierw na dworze ojcowskim. Wydaje się pewnym, że jej sylwetkę wewnętrzną kształtował spowiednik ojca, dominikanin, Peregryn z Raciborza (ok. 1260 - po 1333), wówczas przeor klasztoru św. Jakuba, a następnie prowincjał polskiej prowincji dominikanów (1305-1312) ${ }^{11}$. Możliwe też, że ok. 1306 r. księżniczka została

${ }^{6}$ Przemysł (1258/1276-1306) był najmłodszym synem Władysława opolsko-raciborskiego i Eufemii wielkopolskiej. Urodził się ok. 1276. Po śmierci ojca wraz z bratem Mieszkiem zarządzał cieszyńsko-raciborską częścią domeny ojcowskiej. Współrządy trwały do 1290 i Przemysł tytułował się wówczas księciem opolskim i panem na Oświęcimiu. Od 1290 r., po podziale księstwa, Przemysł tytułował się księciem raciborskim. Rozwinął ekonomicznie swoją ziemię, a szczególną troską otoczył Racibórz, któremu nadał charakter grodu stołecznego i dokonał jego lokacji na prawie magdeburskim 17 czerwca 1299 r.; pięć lat wcześniej lokował Nowe Miasto położone tuż przy Raciborzu. Wspierał dominikanów raciborskich i dokonał w mieście fundacji klasztoru mniszek tego zakonu. Na Nowym Mieście w 1295 r. założył szpital św. Mikołaja wraz z klasztorem bożogrobców, którzy przybyli z Miechowa. Rozbudował też w latach 1281-1287 zamek raciborski. W polityce zewnętrznej stanął po stronie biskupa wrocławskiego, Tomasza II, w jego sporze z księciem Henrykiem IV PrawymW sporze o tron krakowski między Władysławem Łokietkiem i Wacławem II okazał się stronnikiem Przemyślidy. Przemysł przed 1290 r. ożenił się z Anną, córką Konrada II czerskiego, z którą miał dzieci: Leszek (1290), Anna (1296), Eufemia (1299) i córka o nieznanym imieniu (1305/1307). Książę Przemysław zmarł 7 maja 1306 r. i spoczął w kaplicy św. Dominika w budowanym kościele Św. Ducha, dominikanek raciborskich. Zob. M. Kutzner, Racibórz, Wrocław 1965, s. 46-50.

${ }^{7}$ Anna (ok. 1270 - po 1324), córka Konrada II czerskiego i Jadwigi legnickiej. Między 1289 a 1291 r. poślubiła księcia raciborskiego Przemysła. Małżeństwo było efektem planu, mającego na celu zapewnienie królowi Czech Wacławowi II dobrej pozycji w walce o tron krakowski gdyż ojciec Anny i jego brat, Bolesław II płocki pozostawali z nim w ścisłym sojuszu. Dawni badacze uważali, że małżonek Anny uposażył ją dożywotnio Wodzisławiem Śląskim, co obecnie jest stawiane pod znakiem zapytania. Piastówna mazowiecka urodziła syna Leszka i córki: Annę, Eufemię i nieznaną z imienia. Księżna Anna zmarła w Raciborzu po 13 lipca 1324 r. Została pochowana w krypcie kaplicy św. Dominika kościoła dominikanek w Raciborzu. Zob. Piastowie. Leksykon biograficzny, Kraków 1999, s. 279.

${ }^{8}$ Odniesieniem do r. 1299 jako czasu narodzin Ofki był dokument jej ojca wystawiony 1 października 1299 r. jako akt fundacyjny dla klasztoru dominikanek w Raciborzu. Zob. Suchoń, Ofka, Eufemia, Domitilla, s. 160-171.

${ }^{9}$ Rok 1301 pozostaje granicznym dla datowania narodzin Ofki z uwagi na to, że 9 kwietnia 1313 miały miejsce jej zakonne obłóczyny, do których wymagana była pełnoletniość, czyli ukończone 12 lat. Zob. K. Jasiński, Rodowód Piastów śląskich, Kraków 2007, s. 541.

${ }^{10}$ Cod. Dipl. Sil., s. 114-119.

${ }^{11}$ Peregryn (1260-1333). Urodził się ok. 1260 r. w Raciborzu (lub w Opolu). Naukę pobierał w studium dominikanów w Raciborzu, a następnie na którymś z zachodnich uniwersytetów. W 1303 r. 
z woli ojca przekazana raciborskim dominikankom na wychowanie. U nich miała nauczyć się łaciny w piśmie, mowie i czytaniu, śpiewu monastycznego oraz zapewne haftu artystycznego ${ }^{12}$.

Gdy Ofka osiągnęła pełnoletniość, otrzymała (przez nią odrzuconą) propozycję zamążpójścia, najpierw za księcia z Brunszwiku, następnie z Marchii Brandenburskiej ${ }^{13}$. Wstąpiła do klasztoru i w poniedziałek po Niedzieli Palmowej 9 kwietnia 1313 r. miały miejsce u raciborskich dominikanek jej obłóczyny ${ }^{14}$. Tego dnia księżniczka wniosła konwentowi sowity posag ${ }^{15}$. Prawdopodobnie po rocznym nowicjacie (ok. 1314 r.) złożyła uroczyste śluby zakonne. Odtąd Ofka stała się jedną z sióstr profesek chórowych. I choć początkowo nie stała na czele zarządu klasztorem, to $\mathrm{z}$ uwagi na to, że była siostrą księcia, w imieniu konwentu zawierała umowy prawne: w 1316 r. zakupiła od opata cystersów z Rud, Mikołaja cztery jatki mięsne w Żorach ${ }^{16}, 13$ października 1339 r. za 400 grzywien zakupiła od Konrada Stoschowicza z Rogowa wieś Ucieszków i połowę Warmuntowic ${ }^{17}$ oraz w 1340 r. wraz z siostrzenicami-mniszkami, Elżbietą, Agnieszką i Anną, za 6559 marek groszy praskich zakupiła od rycerzy Henryka i Jeszka z Plumlova miasteczko Baborów oraz trzy wsie: Sułków, Czerwonków i Dzielów ${ }^{18}$.

W latach 1317-1334 trwały prace budowlane klasztoru i kościoła dla dominikanek ${ }^{19}$. Ofka jako córka fundatora i siostra księcia raciborskiego na pewno

był przeorem klasztoru św. Jakuba w Raciborzu, gdzie związał się z dworem księcia Przemysła. W 1305 r. był przeorem klasztoru św. Wojciecha we Wrocławiu. Dwukrotnie pełnił urząd prowincjała polskiej prowincji dominikanów (1305-1312 i 1322-1327). W 1310 r. przewodniczył kapitule prowincjalnej dominikanów w Elblągu, która na prośbę papieża wyraziła swoją opinię o zakonie krzyżackim. W 1312 r. Peregryn uczestniczył w kapitule generalnej dominikanów w Carcassonne. W 1318 r. mianowany przez papieża Jana XXII pierwszym inkwizytorem na ziemiach polskich. Urząd ten sprawował do rezygnacji w 1327 r. Zmarł ok. 1333 r., prawdopodobnie we Wrocławiu. Peregryn był znany jako wybitny kaznodzieja. Jego Kazania De tempore i De sanctis, napisane przypuszczalnie w Raciborzu, między 1295 a 1304 r., cieszyły się popularnością w wielu krajach Europy, o czym świadczy blisko 300 zachowanych średniowiecznych kopii rękopiśmiennych. Po wynalezieniu druku zbiór kazań Peregryna doczekał się szeregu wydań. Jeszcze w XV w. ukazało się 7 edycji oficyn niemieckich z Kolonii, Strassburga czy Ulm. Zob. Peregrini de Opole, Sermones de tempore et de sanctis, wyd. R. Tatarzyński, Warszawa 1997; G. Gieraths, Peregrinus, OP, Predigtschriftsteller, w: Lexikon für Theologie und Kirche, t.8, Freiburg 1986, k.270; J. Wolny, Laciński zbiór kazań Peregryna z Opola i ich zwiazek z tzw. „,Kazaniami Gnieźnieńskimi”, w: Średniowiecze. Szkice o kulturze, t.1, red. J. Lewański, Warszawa 1961, s.171-238; tenże, Peregryn z Opola, PSB, t. 25, Wrocław 1980, s. 598-602; P. Newerla, Opowieści o dawnym Raciborzu, Racibórz 1996.

${ }^{12}$ G. Kublin, Średniowieczne i nowożytne „,testimonia sanctitatis” Eufemii raciborskiej (zm. 1359), „Folia Historica Cracoviensia”, 19 (2013) s. 77.

${ }^{13}$ Propago D. Hyacinthi Thravmaturgi Poloni seu De rebus praeclare gestis in Prouincia Poloniae Ordinis Praedicatorum. Commentarius. F. Abraham Bzovii Sacrae Theologiae Magistrii, Ord. Praedic., Venetiis 1606, s. 48.

${ }^{14}$ Cod. Dipl. Sil., s. 122-123.

${ }^{15}$ Tamże, s. 123-124.

${ }^{16}$ Tamże, s. 126.

${ }^{17}$ Tamże, s. 138.

${ }_{18}^{18}$ Tamże, s. 140-141

${ }^{19}$ Kublin, Świątobliwa Eufemia raciborska (†17 I 1359), s. 19. 
zaangażowała się w budowę. Konsekracji kościoła pw. Świętego Ducha dokonał biskup wrocławski, bł. Nanker Oksza 29 września 1334 r., jak o tym czytamy w dokumencie z 1 czerwca $1335^{20}$. Wcześniej z uwagi na Ofkę, jej brat, Lestek $(1290 / 1292-1336)^{21}, 25$ lutego 1317 r. potwierdził dominikankom raciborskim własność terenu pod budowę świątyni zakonnej. Piastówna cieszyła się dużym poważaniem w społeczeństwie. Należy wspommnieć, że powstałe w 1334 r. w farze raciborskiej maryjne bractwo literackie uważało Ofkę za swą założyciel$\mathrm{kę}^{22}$, a w aktach kapituły polskiej prowincji dominikanów zapisano w 1338 r. obligacje modlitewne w intencji mniszek raciborskich: Ofki Piastówny raciborskiej i Elenczy Piastówny kozielskiej, gdzie pierwszą nazwano z szacunkiem antiqua czyli znakomita: pro [...] Ducissa Rath[iboriensi] antiqua Offca et Elenka sororibus Ordinis nostri ${ }^{23}$.

Na przełomie lat 30. i 40. XIV wieku Racibórz i okolice nawiedziła klęska szarańczy, która spustoszyła pola i sady, a następnie powódź. W takich okolicznościach w 1341 r. Ofka została przez konwent dominikanek raciborskich wybrana przeoryszą. Pierwszy zachowany dokument tytułujący ją przeoryszą pochodzi z 9 czerwca $1341 \mathrm{r}^{24} \mathrm{Z}$ niego dowiadujemy się też o świętowaniu w klasztorze Bożego Ciała wraz z oktawą. Stojąc na czele konwentu musiała zmierzyć się $\mathrm{z}$ wieloma wyzwaniami. Wystarała się, aby 2 lutego 1343 r. nowy (od 14 stycznia 1337 r.) książę raciborsko-opawski Mikołaj II Przemyślida (ok. 1288-1365)25

${ }^{20}$ Cod. Dipl. Sil., s. 134-135; A. Weltzel, Geschichte der Stadt Ratibor, Ratibor 1861, s. 489; Schaffer, Geschichte, s. 171.

${ }^{21}$ Lestek (1290/1292-1336), był jedynym synem Przemysła raciborskiego. Urodził się między 1290 a 1292 r. Księstwo raciborskie objął po śmierci ojca 7 maja 1305 r. Z powodu małoletniości opiekował się nim i regencję nad księstwem sprawował stryj, książę Mieszko cieszyński. Lestek przez 20 lat był księciem niezależnym. W dniu 19 lutego 1327 w Opawie złożył hołd lenny królowi czeskiemu Janowi Luksemburskiemu, który zabezpieczył dla jego potomstwa sukcesję. Lestek wstąpił przed 3 stycznia 1333 r. w związek małżeński z Agnieszką, córką Henryka IV Wiernego, księcia głogowsko-żagańskiego. Małżonkowie potrzebowali dyspensy papieskiej z uwagi na bliskie pokrewieństwo. Małżeństwo było bezdzietne. Lestek objął od księcia bytomskiego Władysława w zastaw 21 lutego 1334 r. księstwo kozielskie i Bytom. Około 1318 r. wydał za mąż swą siostrę Annę za księcia opawskiego, co dało później powód, by księstwo raciborskie przejęła boczna linia dynastii Przemyślidów. Książę był opiekunem swej siostry Ofki i donatorem jej klasztoru. Lestek zmarł jako ostatni Piast raciborski w 1336 r. i spoczął w kaplicy św. Dominika kościoła dominikanek raciborskich. Zob. S. Solicki, Leszek (Leszko), PSB, t. 17, Wrocław 1972, s. 161; A. Weltzel, Geschichte der Stadt, s. 65-73.

${ }^{22}$ Liber albus confraternitatis in ecclesia collegiata Rattiboriae sub titulo Gloriosa Virginis Mariae in Coelos Assumptae, w: H. Schaffer, Geschichte einer schlesischen Liebfrauengilde seit dem Jahre 1343, Ratibor 1883, s. XXVII

${ }^{23}$ M. Zdanek, Fragment akt kapituly prowincjalnej dominikanów polskich z 1338 r., „,Roczniki Historyczne", 76 (2010) s. 271; Kublin, Średniowieczne i nowożytne, s. 83.

${ }^{24}$ Cod. Dipl. Sil., s. 146-147.

${ }^{25}$ Mikołaj II Przemyślida (1288-1365), był najstarszym synem księcia Mieszka I pochodzącego z bocznej linii dynastii Przemyślidów i Adelajdy, siostrzenicy króla Niemiec Rudolfa Habsburga. Urodził się ok. 1288 r. W 1312 r. uczestniczył w buncie przeciwko władzy Jana Luksemburskiego. Wkrótce jednak stał się bliskim doradcą króla w sprawach Śląska. W 1318 r. otrzymał jako dziedziczne lenno księstwo opawskie z Opawą, Głubczycami, Bruntalem i Karniowem. W 1337 r. po 
potwierdził nabycie przez dominikanki zwierzchniego prawa książęcego i 20,5 włók czynszowych w Bieńkowicach za 220 marek $^{26}$. Następnie 8 czerwca $1343 \mathrm{r}$. poleciła sporządzić transumpt przywileju z 1340 r. zatwierdzający zakup Baborowa i trzech wsi $^{27}$.

Podczas wojny w 1345 r., w którą zaangażował się książę Mikołaj II, król Kazimierz Wielki z posiłkami węgierskimi i litewskimi zaatakował księstwo raciborskie. W odpowiedzi na to król Jan Luksemburczyk w końcu czerwca z armią dotarł pod Racibórz. W tej sytuacji, Ofka wystąpiła do papieża Klemensa VI z prośbą, aby klasztor dominikanek raciborskich i jego dobra wziął pod opiekę Stolicy Apostolskiej. Niebawem z Awinionu otrzymała stosowne breve datowane na 2 lipca $1345 \mathrm{r}^{28}$

W tym czasie Ofkę spotkały liczne przykrości i uciążliwości (gravamina) z powodu kradzieży jej pieniędzy z zakrystii przez jednego z dominikanów. Uruchomiła całą procedurę prawną, odwołując się do kapituł prowincji w Toruniu, Krakowie i Legnicy oraz prowincjała. Wobec opieszałości w wyjaśnianiu kradzieży sprawa oparła się o generała zakonu Piotra Gaume ${ }^{29}$. Jeszcze w 1345 r. Ofka poprosiła prowincjała Stanisława z Krakowa o zwolnienie z funkcji przeoryszy $^{30}$. Przez kolejne trzy lata (1346-1349) na czele dominikanek raciborskich stała mniszka o imieniu Gertruda. Jednak podczas nowych wyborów w 1349 r. mniszki wybrały ponownie Ofkę przeoryszą ${ }^{31}$. Ta zaś poprosiła, aby książę kozielski Bolko potwierdził prawa klasztoru do wsi Warmuntowice. Uczynił to 21 grudnia $1349 \mathrm{r}^{32}$

śmierci Leszka raciborskiego, jako szwagier zmarłego otrzymał z rąk Jana Luksemburskiego księstwo raciborskie. Utracił jednak na rzecz Bolka niemodlińskiego okręg prudnicki. W Raciborzu pozostawił w swoim otoczeniu doradców zmarłego księcia. Otaczał szczególną opieką klasztor dominikanek w Raciborzu i dominikanów w Opawie. W 1358 r. aktywnie włączył się w przyjęcie chrztu przez książąt litewskich. Mikołaj II współpracował najpierw z królem Janem, potem z Karolem IV. Wielokrotnie był przez nich posyłany w misjach dyplomatycznych do Polski, Niemiec, na Litwę i do Rzymu. Mikołaj II był trzykrotnie żonaty. Pierwszą żoną była poślubiona ok. $1318 \mathrm{r}$. Anna Piastówna raciborska (†1340), z którą doczekał się sześciorga potomstwa (Jana I, Eufemii wydanej za Siemowita III mazowieckiego, Elżbiety dominikanki raciborskiej, Agnieszki dominikanki raciborskiej, Anny wydanej za Burcharda hr. Hardeck und Maidburg i Małgorzaty żony margrabiego Moraw Jana Henryka Luksemburga). Po raz drugi Mikołaj ożenił się ok. 1358 r. z Jadwigą Piastówną oleśnicką (†1359), córką Konrada I, z którą miał syna, Mikołaja III. Trzeci raz książę ożenił się ok. 1360 r., tym razem z Jutą Piastówną niemodlińską (†1379), córką Bolesława. W posagu przyjął na powrót ziemię prudnicką. Juta obdarzyła go potomstwem: Wacławem, Przemkiem i Anną wydaną za Piotra ze Sternberka. Mikołaj II Opawski zmarł 8 grudnia 1365 i zapewne został pochowany w którymś z kościołów opawskich. Zob. M. Capsky, Historia Górnego Śląska. Polityka, gospodarka i kultura europejskiego regionu, Opava 2011, s. 122.

${ }^{26}$ Cod. Dipl. Sil., s. 147-148.

${ }^{27}$ Tamże, s. 149.

${ }^{28}$ Tamże, s. 150.

${ }^{29}$ Kublin, Sprawa zagubienia, s. 493-499.

${ }^{30}$ Suchoń, Ofka, Eufemia, Domitilla, s. 165.

${ }^{31}$ Tamże, s. 165; Kublin, Eufemia raciborska - priorissa, s. 293.

${ }^{32}$ Cod. Dipl. Sil., s. 160-161. 
Przeorat Ofki przypadł na trudne czasy. Jeszcze w 1349 r. do Raciborza dotarła przywleczona z zachodu Europy Czarna Dżuma. Groza towarzyszyła mieszkańcom przez rok. W 1350 r. wylała Odra. Kataklizmy osłabiły materialną kondycję klasztoru dominikanek. By zaradzić kłopotom 9 sierpnia 1352 r. Ofka zakupiła za 20 marek cztery pozostałe włóki w Bieszkowie, zaokrąglając tym sposobem nabytek będący posagiem mniszki Klary z Linawy ${ }^{33}$. Na wniosek przeoryszy (Ofka pozostawała na urzędzie na kolejną, trzyletnią kadencję), rada miejska Raciborza 15 grudnia 1352 r. poświadczyła sprzedaż dominikankom przez Frytka Strala wsi Ligota Wielka ${ }^{34}$. Nabytki jednak musiały być niewystarczające, gdyż klasztor mniszek raciborskich znalazł się w niedostatku. Zubożenie wynikało $\mathrm{z}$ trudnej sytuacji ekonomicznej w kraju, zrujnowaniem dóbr oraz kłopotów z egzekwowaniem należności przez klauzurową wspólnotę sióstr, w wielu przypadkach zdanych na zarządców i dzierżawców. W tej sytuacji, aby wspomóc materialnie zakonnice, biskup wrocławski Przecław z Pogorzeli wystawił w Otmuchowie 13 stycznia 1354 r. dla dominikanek dokument, dotyczący nadania konwentowi dziesięciny snopowej z Małej Grudyni, która należała do stołu biskupiego ${ }^{35}$. Dokument został wystawiony na wniosek właściciela Małej Grudyni, Henryka z Głubczyc. Ponadto szwagier Ofki, książę raciborsko-opawski Mikołaj II Przemyślida, na prośby swych córek, mniszek raciborskich, Agnieszki i Elżbiety oraz wnuczki, Elżbiety von Maidburg und Hardeck, 30 września 1354 r. uwolnił zakonnice od płacenia 15 grzywien czynszu rocznego z miasteczka Baborów ${ }^{36}$.

Ofka Piastówna zmarła w czwartek 17 stycznia 1359 r. i spoczęła w krypcie pod kaplicą św. Dominika, która była mauzoleum grobowym jej krewnych i która przylegała do kościoła klasztornego raciborskich dominikanek ${ }^{37}$. Po śmierci Ofkę otoczył kult wiernych, który trwa nieprzerwanie. Materialnie ten kult jest potwierdzony od początku XVII w. i ma znamiona ciągłości do dziś. Liturgicznie Ofka Piastówna jest wspominana jako świątobliwa lub błogosławiona 17 stycznia albo 26 listopada.

Należy podkreślić, że istnieją dwa testamenty Piastówien w habitach. Pierwszy należał do bł. Salomei Piastówny krakowskiej (1211/1212-1268), córki princepsa Leszka Białego, małżonki królewicza węgierskiego Kolomana, księżny chorwacko-slawońskiej, a po owdowieniu mniszki Zakonu św. Klary, który w 1245 r. sprowadziła z Pragi do Polski. Testament został sporządzony w klasztorze klarysek w Skale 30 sierpnia 1268 r. na życzenie Salomei i w obecności brata Piastówny, księcia Bolesława Wstydliwego, biskupa krakowskiego Pawła z Prze-

${ }^{33}$ Tamże, s. 152.

${ }^{34}$ Tamże, s.153-154.

${ }^{35}$ Tamże, s. 154-155.

${ }^{36}$ Tamże, s. 155.

${ }^{37}$ Archiwum Państwowe we Wrocławiu, rep. 135, sygn. 582, Das Leben der Hochseeligen Jungfrau Euphemiae Domicillae, des Herzog Premislai Lesconis Tochter, und Fundatricis des Jungfräuliches Klosters Beym Heyligen Geist in Rattibor, Ord. S. Dominici Beschreiben von Miechovio und Bzovio Pohlnischen Authoribus in Chronica ad Annum 1359. 
mankowa oraz dziewięciu franciszkanów ${ }^{38}$. Sam dokument wraz z przytroczoną do niego pochodzącą z XV w. pieczęcią ${ }^{39}$ zachował się w klasztorze klarysek krakowskich. Mając status fundatorki klasztoru, nie zaś ksieni, Salomea, profeska Zakonu św. Klary, rozdysponowała swą własność, przekazując wszystkie dobra wiejskie na własność klasztoru, natomiast „,rzeczy, które posprawiała na chwałę Bożą i Świętych Jego, jak też na ozdobę Domu Bożego"40 przepisała Salomei Piastównie mazowieckiej, klarysce w Skale, by była ich kustoszką. Natomiast „Księgi chórowe i naukowe" zapisała franciszkanom mającym pieczę nad klasztorem klarysek, jako ich kapelani, spowiednicy i kierownicy duchowi ${ }^{41}$.

Testament Salomei Piastówny jest pierwszym, jaki na ziemiach polskich sporządziła mniszka zakonu będącego żeńską gałęzią mendykanckich minorytów. Inny, także mniszki z drugiego zakonu mendykantów, braci kaznodziejów, został spisany w dziewięćdziesiąt lat później i uwierzytelniony został prawnie przez przeoryszę raciborskich dominikanek, Ofkę Piastównę, która do dokumentu poleciła przytwierdzić swą pieczęć. Także wówczas panujący w Raciborzu książę Mikołaj II Przemyślida uznał wolę przeoryszy dominikanek i dołączył swoją pieczęć. Podobnie jak Salomea, Ofka swą ostatnią wolą pragnęła zapewnić pomyślność swego klasztoru. Uczyniła to jednak w nieco odmienny sposób. Przeczuwając swą śmierć, wezwała do klasztoru księcia raciborsko-opawskiego Mikołaja II, jego syna Jana I i prowincjała dominikanów Piotra z Chomiąży. Obecni byli także: rycerz Henryk Hoberg, spowiednik mniszek brat Jan, notariusz publiczny Piotr Gotfridi, proboszcz kościoła św. Mikołaja z raciborskiej Starej Wsi a także protonotariusz książęcy Franciszek, proboszcz z Grodźca koło Opawy. W ich obecności wyraziła prawnie swą ostatnią wolę i poleciła sporządzić testament rozpoczynając go od inwokacji: „Nos Eufemia quondam Illustris Principis... Priorissa Claustri seu Monasterij Virginum”. Treść testamentu spisał Piotr Gotfridi, natomiast sam pergamin przygotował per manus protonotariusz księcia raciborsko-opawskiego Mikołaja II, Franciszek z Grodźca koło Opawy.

Chcąc, by osiadła przed dwudziestu jeden lat w Raciborzu dynastia Przemyślidów zabezpieczyła klasztorowi dominikanek byt i rozwój oraz przyjęła wobec niego prawo patronackie, Ofka swymi głównymi spadkobierczyniami uczyniła własne siostrzenice, Agnieszkę i Elżbietę Przemyślidówny, córki panującego księcia Mikołaja II, a zarazem mniszki dominikańskie w Raciborzu. Przekazała im wszystkie rzeczy osobiste oraz dobra. Były nimi: miasto Baborów wraz z wsiami do niego należącymi: Dzielowem, Czerwonkowem i Sułkowem, cztery wsie: Lyski, Pogrzebień, Lubomia i Markowice, czynsze roczne: z dziesięciu jatek mięsnych w Żorach w postaci „półpięta bryły topionego i czystego łoju na św. Marcina", od każdego sukiennika raciborskiego 9 grzywien polskich i 9 skojców „na świętego Gawła”, od każdego kramu w Raciborzu 8 skojców, 6 skojców

${ }^{38}$ Codex diplomaticus Minoris Poloniae, red. F. Piekosiński, t. 3, nr 76, Kraków 1876-1905; polskie thumaczenie w: C. Niezgoda, Błogosławiona Salomea Piastówna, Kraków 1996, s. 128.

${ }^{39}$ Niezgoda, Błogosławiona Salomea Piastówna, s. 130; T. Żebrawski, O pieczęciach dawnej Polski i Litwy, Kraków 1865, s. 25.

${ }^{40}$ Cod. Min. Pol., t. 3, nr 76.

${ }^{41}$ Tamże. 
od każdego łanu „przed Raciborzem leżącego”, 9 grzywien polskich i 6 skojców od nowo lokowanych miejscowości, należących do Raciborza, 60 groszy od 10 domów przy ulicy Szerokiej i od innych dziesięciu „stojących na fosie”, wraz ze „wszystkimi innymi”, które występują w Proszowcu. Do tych dóbr dodała jeszcze dwie wsie, Bojanów i Bieszków. Te same prawa na tychże dobrach otrzymała inna Piastówna i dominikanka raciborska, Anna, wnuczka Mikołaja II Przemyślidy. Miała ona zagwarantowane prawa do dóbr przepisanych Agnieszce i Elżbiecie Przemyślidównym, po ich śmierci, z zastrzeżeniem, że nie dotyczy to czterech wsi (Lyski, Pogrzebień, Lubomia i Markowice). Anna Piastówna otrzyma także przypadające Elżbiecie Przemyślidównie: połowę wsi Sucha Psina i wieś Ucieszków wraz z folwarkami Warmuntowice i Modzurów. Ofka zdecydowała również, że gdyby syn władcy, książę Jan I Przemyślida raciborski miał córkę, i gdyby wstąpiła ona do klasztoru raciborskiego, wówczas - wraz z Anną Piastówną - gospodarowałaby na zapisanych dobrach. Ten zapis okazał się martwy wobec niewstąpienia Janowej córki Małgorzaty do dominikanek. Na koniec Ofka poleciła, że po śmierci mniszek-księżniczek, które były gwarantkami niepodzielności dóbr i całości jego dochodów, należy uznać je jako własność konwentu raciborskich dominikanek i ,mają należeć po wieczne czasy i być rozwijane [jako dobra] konwentu sióstr i panien we wspomnianym klasztorze raciborskim, bez jakiejkolwiek przeszkody, sprzeciwu i odmowy".

Testamentem Ofka zobowiązała wszystkie pokolenia profesek klasztoru raciborskiego, ,aby także z racji pobieranych dochodów oraz naszej darowizny” odprawiały modlitwy za jej zmarłych rodziców, księcia Przemysła i księżny Anny oraz odmawiały akty strzeliste za jej nieżyjącego brata, księcia Lestka.

Aby zaś zabezpieczyć duchowe i religijne potrzeby dominikanek zdecydowała, aby z dochodów wsi Ucieszków przeznaczyć 10 grzywien polskich, „zamiast piwa" dla klasztoru dominikanów w Raciborzu, w zamian za co każdorazowy przeor był zobowiązany wysyłać codziennie czterech kapłanów do odprawiania śpiewanych mszy św. w kościele dominikanek.

Rozdysponowawszy swoją własność Ofka oświadczyła „z całkowitą szczerością, że ani za życia, ani w chwili śmierci” tego testamentu nie odwoła, nawet jeśliby doszłyby do jej uszu wiadomości sugerujące potrzebę zmiany. Poprosiła też księcia raciborsko-opawskiego Mikołaja II i jego syna Jana I, aby jej wolę prawnie usankcjonowali i potwierdzili. Jej prośbie stało się zadość.

Z dyspozycji testamentowej wynika, że Ofka w 1358 r., tak samo, jak Salomea w 1268 r. uważała, że w aktualnej sytuacji społeczno-politycznej jedynie mniszki będące członkiniami domu panującego, były w stanie zachować nienaruszony stan posiadania klasztoru. Miały wystarczająco mocną pozycję i znajomość rzeczy, aby wziąć za wszystko odpowiedzialność. Konwent dominikanek raciborskich składał się wtedy z zakonnic pochodzących z najwyższych sfer i w przeciwieństwie do skalskich klarysek sprzed dziewięćdziesięciu lat, pośród których przebywały siostry z wszystkich stanów, nawet chłopki, będą one umiały docenić wartość dzieł sztuki, paramentów czy ksiąg. Dlatego żadnych „,rzeczy posprawianych na chwałę Bożą”, czy „ksiąg chórowych i naukowych”, których u mniszek 
raciborskich również nie brakowało, nie trzeba było zabezpieczać testamentem przed ewentualnym nieroztropnym wydaniem z klasztoru.

Nasuwa się pytanie: jak to możliwe, że Ofka, profeska dominikańska zobowiązana do ubóstwa partykularnego, w ogóle mogła sporządzić testament bez naruszenia norm zakonnych. Było to możliwe na podstawie specjalnego indultu Stolicy Apostolskiej dla raciborskich dominikanek, które uzyskały pozwolenie na posiadanie własności prywatnej dla wspólnej korzyści (proprium in communi) ${ }^{42}$. Poszczególne siostry mogły z dóbr korzystać za zgodą przeoryszy. Tego typu rozwiązania były przyjęte we wszystkich klasztorach dominikanek na ziemiach polskich (nie tylko dominikanek) i utrzymały się aż do XIX w., a w szczątkowych formach nawet do pierwszej dekady XX w. Z tej przyczyny Ofka miała prawo dysponować swymi dobrami i je zapisywać w testamencie, zwłaszcza, że była nie tylko przeoryszą, ale członkinią rodu panującego oraz córką i siostrą prawnych fundatorów klasztoru.

Znaczenia testamentu Ofki dla klasztoru dominikanek raciborskich było kluczowe. Rzeczywiście jego rozporządzenia stały u podstaw ekonomicznej pomyślności konwentu aż do pierwszej dekady XV w. Póki żyły we wspólnocie księżniczki, beneficjentki zapisu, integralność latyfundium była zapewniona. Pierwsza zmarła Elżbieta Przemyślidówna (1386 r.), natomiast już w XV w. zmarły: Anna Piastówna (1403) i Agnieszka Przemyślidówna (1404). Do tego czasu zmarły również inne księżniczki-mniszki: Anna Przemyślidówna, córka Mikołaja II opawskiego, wdowa lub rozwódka po Burchardzie hrabim Hardeck i jej córka Elżbieta Maidburg und Hardeck oraz wymieniona w 1361 r. Kunegunda Piastówna mazowiecka. Po ich śmierci dochodziło do prób zagarnięcia własności klasztornej. Już w 1421 r. rycerz rozbójnik (raubritter) Mikołaj Zedlina odebrał siostrom trzy wsie. Jak można zauważyć decyzja Ofki, aby dobra klasztorne przekazać formalnie mniszkom-księżniczkom okazała się bardzo trafna i skuteczna na co najmniej dwa pokolenia.

Dla polskiej historiografii testament Ofki Piastówny pozostaje istotnym źródłem do badań nad sposobami zabezpieczenia fundacji klasztornych, które podejmowały ich książęce fundatorki. Dysponujemy treścią dwóch takich aktów, jednym - Salomei Piastówny OSC, który pochodzi z połowy XIII w. - szeroko znanym i publikowanym po łacinie i po polsku i drugim - Ofki Piastówny OP z XIV w. - oszczędnie traktowanym przez polską historiografię. Porównując oba należy wskazać, że dwie księżniczki, niezależnie od siebie, postanowiły pójść drogą zabezpieczenia majątku poprzez przekazanie go pod kuratelę przebywających z nimi w klasztorze innym córkom książęcym. Ich prestiż i pozycja społeczna miały być wystarczającym zabezpieczeniem. Testamenty tworzyły dodatkowe prawne podwaliny pod rozwój latyfundiów obu żeńskich klasztorów klauzurowych (klarysek w Skale i dominikanek w Raciborzu), których egzystencja oparta była wyłącznie o posiadłości i czynsze. Były przez mniszki obu konwentów uważane za dokumenty podstawowej wagi i pieczołowicie przechowywane w archiwach. Testament Salomei jest nadal w posiadanie krakowskich klarysek,

\footnotetext{
${ }^{42}$ Cod. Dipl. Sil., s. 150.
} 
natomiast ostatnia wola Ofki została dominikankom raciborskim zarekwirowana przez rząd króla pruskiego Fryderyka Wilhelma III w czasie sekularyzacji ich wspólnoty.

Należy podkreślić, że testament Ofki Piastówny wpisywał się w prawno-kanoniczną praktykę sporządzania tego typu dokumentów ${ }^{43}$. Był też wyrazem ówczesnej sytuacji społecznej i ekonomicznej Górnego Śląska. W tę rzeczywistość wpisywał się konwent raciborskich dominikanek, jako jeden z trzech (obok norbertanek w Czarnowąsach i klarysek w Opawie) ważnych ośrodków duchowych i kulturotwórczych tworzonych przez mniszki.

$* * * *$

Codex Diplomaticus Silesiae, wyd. W. Wattenchbach, t. II, Urcunden der Dominikaner und Dominikanerinnen in der Stadt Ratibor, Breslau 1892, s. 156158.

\author{
8 gr[udnia] 1358
}

My Eufemia, ongiś córka prześwietnego księcia i pana Przemysła, władcy Raciborza, przeorysza klasztoru czyli konwentu panien i sióstr w Raciborzu, wyznajemy i potwierdzamy wszystkim obecnym, że po dojrzałym rozważeniu, pozostając w pełni władz umysłowych, co do dóbr udzielonych nam przez Boga, a przez naszych przodków słusznie i rozumnie pomnożonych, taki czynimy zapis testamentowy. Po pierwsze i przede wszystkim, na rzecz szlachetnych córek niegdyś siostry naszej, znamienitej pani Anny ${ }^{44}$, małżonki najjaśniejszego księcia i pana, pana Mikołaja, władcy Opawy i Raciborza, z niego samego zrodzonych, panny Elżbiety ${ }^{45}$ i panny Agnieszki ${ }^{46}$, przebywających z nami w tym samym

${ }^{43} \mathrm{R}$. Dembska, O testamencie polskim w polskim prawie średniowiecznym, w: Studia z historii ustroju i prawa. Księga dedykowana Profesorowi Jerzemu Walachowiczowi, red. H. Olszewski, „Prace Wydziału Prawa i Administracji Uniwersytetu im. A. Mickiewicza w Poznaniu”, 7 (2002) s. 70.

${ }^{44}$ Anna (1296 - przed 22 sierpnia 1340), druga córka Przemysła i Anny. W 1318 oddana za żonę Mikołajowi II Przemyślidzie opawskiemu. Domniemana dziedziczka księstwa raciborskiego. Anna była drugą żoną Mikołaja i matką dzieci: Jana I (1332-1380/1382), ks. Opawy i Raciborza w latach 1365-1380/1382 i od 1377 tylko Raciborza, Mikołaja III głubczyckiego (†1394), Wacława opawskiego (†1381), Elżbiety, dominikanki (†1386), Agnieszki, dominikanki (†1404), Anny i Małgorzaty. Anna zmarła w Opawie w 1340 r. Zob. A. Kłodziński, Anna, PSB, t. 1, Kraków 1935, s. 119; Piastowie, s. 740.

${ }^{45}$ Elżbieta Przemyślidówna opawska, córka (prawdopodobnie trzecie dziecko) Mikołaja II i Anny Piastówny raciborskiej. Urodziła się najwcześniej w latach dwudziestych. Od dzieciństwa wychowywana pod kierunkiem ciotki Ofki w klasztorze dominikanek w Raciborzu, do którego wstąpiła i tam złożyła profesję zakonną. Elżbieta zmarła w 1386 r. i została pochowana w klasztornej kaplicy św. Dominika.

${ }^{46}$ Agnieszka Przemyślidówna opawska, córka Mikołaja II i Anny Piastówny. Urodziła się po Elżbiecie. Razem z nią oddana na wychowanie do klasztoru dominikanek w Raciborzu, gdzie zło- 
klasztorze, ogólnie wszystkie, a szczególnie drobne nasze rzeczy, bez względu na ich wartość, albo miejsce ich położenia, prawem własności do nas należące, przekazujemy, dajemy, zarządzamy, przyznajemy i nieodwołalnie [z nich] rezygnujemy. Po pierwsze cztery wsie, leżące w ziemi raciborskiej, po drugiej stronie rzeki, zwanej powszechnie Odrą, a to Liski ${ }^{47}$, Pogrebine ${ }^{48}$, Luboma ${ }^{49}$, Marcouicze $^{50} \mathrm{z}$ folwarkami, młynami, stawami rybnym, [z prawem] odławiania ryb, łąkami, lasami, gajami, zagajnikami i ze wszystkimi swoimi przynależnościami

żyła profesję zakonną. Była szeregową mniszką. Dożyła sędziwego wieku. Zmarła w 1404 r. i została pochowana w krypcie kaplicy św. Dominika.

${ }^{47}$ Wieś zwana po polsku Lyski a po niemiecku Lissek, położona w województwie śląskim, w powiecie rybnickim. Od XIV w. posiada kościół parafialny pw. św. Małgorzaty. W Lyskach znajduje się pałac z XIX w. oraz dom pomocy społecznej pw. św. Józefa. W okresie II wojny światowej Niemcy utworzyli w miejscowości jeden z obozów koncentracyjnych przeznaczonych dla Polaków, tzw. Polenlager 56. Zob. Lyski, w: Encyklopedia powstań śląskich, Opole 1982, s. 283.

${ }^{48}$ Wieś zwana po polsku Pogrzebień, a po niemiecku Pogrzebin, położona w gminie Kornowac (Kornowatz). Leży nad doliną Odry. Po raz pierwszy wzmiankowana w 1258 r. Od 1313 r. należała do klasztoru dominikanek jako posag bł. Ofki Piastówny. W 1800 r. dobra nabył Jan Nepomucen Larisch, ojciec Luizy, która w 1815 r. wyszła za mąż za Josepha von Eichendorffa. Od 1882 r. w posiadaniu Artura Baildon. Wieś słynie z pałacu będącego siedzibą najpierw Larischów, a następnie von Baildonów. W 1930 r. posiadłość przejęli salezjanie. W latach II wojny światowej w pałacu na krótko utworzono obóz przejściowy dla reemigrantów niemieckich z Besarabii oraz Bukowiny. Następnie utworzono obóz dla ludności polskiej pod nazwą Polenlager 82, który z kolei stał się obozem dla dzieci, tzw. Kinderlager. Obecnie w pałacu jest klasztor sióstr salezjanek, które nabyły go w 1946 r. Żyła w nim s. Laura Meozzi (ur. 5 stycznia 1873 r. we Florencji), która w 1922 r. zapoczątkowała w Polsce zgromadzenie sióstr salezjanek. Zmarła mając 78 lat, 30 sierpnia $1951 \mathrm{r}$. w Pogrzebieniu. Jej proces beatyfikacyjny na stopniu diecezjalnym zakończył się w 1994. W Pogrzebieniu znajduje się kościół pw. św. Bartłomieja, który został wybudowany w 1851 r., w stylu neoromańskim i przebudowany w latach 1955-1960. Przed wejściem znajduje się sarkofag s. Laury Meozzi. Stoi on na miejscu poprzedniego kościoła sięgającego początku XIV w. Zob. G. Wawoczny, Zabytki powiatu raciborskiego, Racibórz 2007, s. 4.

${ }^{49}$ Wieś zwana po polsku Lubomia, a po niemiecku Lubom, położona w województwie śląskim, w powiecie wodzisławskim, w gminie Lubomia. Pierwsza wzmianka o Lubomi jest datowana na 1303 r. Ocalały ślady obwałowań i resztki fosy średniowiecznego zamku (XIV w.) na wzgórzu Kotówka. Zgodnie z lokalną legendą pan na zamku słynął z okrucieństwa. Identyfikuje się go z księciem raciborskim Janem II Żelaznym. Zamek prawdopodobnie został zniszczony w wyniku najazdu husytów na księstwo raciborskie. Od 1572 r. Lubomia znajdowała się w rękach rodu Reiswiców, a w 1730 r. przeszła w ręce księcia Franciszka Leopolda Lichnowskiego. Na uwagę w Lubomi zasługują: fragment grodziska, drewniana kaplica pod wezwaniem św. Jana Nepomucena z ok. 1700 r. oraz murowany, neogotycki kościół parafialny pw. św. Marii Magdaleny wzniesiony w 1886 r., z zabytkami pochodzącymi z kościoła drewnianego stojącego na tym samym miejscu.

${ }^{50}$ Dawna wieś zwaną po polsku Markowice, a po niemiecku Markowitz, od 1977 r. w obrębie Raciborza. Została wzmiankowana w dokumencie z 1290 r. Od 1313 r. należała do uposażenia Ofki Piastówny. W 1936 r. w ramach programu germanizacyjnego zmieniono nazwę wsi na Markdorf. Markowice są parafią wzmiankowaną w dokumentach z 1358 r., 1376 r. oraz w rejestrze świętopietrza z 1447 r. Obecna neogotycka świątynia pw. św. Jadwigi Śląskiej powstała w latach 1874-1877 na miejscu drewnianego kościoła. Konsekracji dokonano w 1883 r. W Markowicach urodził się Arka Bożek, w którego domu rodzinnym urzadzono izbę pamięci. Zob. Wawoczny, Zabytki powiatu raciborskiego, s. 62. 
i ciężarami. Następnie, w mieście Sarensi ${ }^{51}$, od 10 jatek będzie od każdej uiszczana półpięta bryły topionego i czystego łoju na św. Marcina ${ }^{52}$. Podobnie w Raciborzu, od każdego sukiennika będzie płacony czynsz dziewięciu grzywien polskich i dziewięciu skojców co roku, na świętego Gawła. Również od każdego kramu 8 skojców na to samo święto. Poza tym, od każdego łanu przed Raciborzem leżącego, będzie płacony czynsz sześciu skojców rocznie. Prócz tego każdego roku od nowych ${ }^{53}$ miejscowości, należących do Raciborza, 9 grzywien polskich i 6 skojców. Również od 10 domów przy ulicy Szerokiej i od dziesięciu(?) stojących na fosie jedna kopa groszy ${ }^{54}$ samego czynszu wraz ze wszystkimi innymi, które występują w Prosuinkel ${ }^{55}$. Prócz tego wszystkiego dajemy i dołączamy także wieś Bougnou $^{56} \mathrm{z}$ folwarkiem i przynależnościami, użytkami i powszechnymi cięża-

${ }^{51}$ Żory, niemiecka nazwa Sohrau i czeska Žory, miasto na prawach powiatu w województwie śląskim. Położone na Płaskowyżu Rybnickim nad rzeką Rudą. W drugiej połowie IX w. teren znajdował się w granicach państwa wielkomorawskiego, a następnie, ok. 921 r. - czeskiego. Po raz pierwszy nazwa wsi Żory pojawiła się w 1258. W dniu 24 lutego 1272 książę opolsko-raciborski Władysław dokonał lokacji miasta na prawie magdeburskim. Miało ono obowiązujący do dziś owalny kształt z prostokątnym rynkiem, dwiema bramami (krakowską i cieszyńską) i murami. Od $1336 \mathrm{r}$. w rękach Przemyślidów. W latach 1345, 1433 i 1473 Żory były oblegane odpowiednio przez wojska polskie, husyckie i węgierskie. W latach 1521-1532 księstwo po raz ostatni znajdowało pod władaniem Piasta, po czym władzę na 20 lat przejęli Hohenzollernowie. W 1526 r. Żory stały się częścią państwa Habsburgów. W 1627 r. podczas wojny trzydziestoletniej wojska protestanckie zajęły Żory. Następnie wojska katolickie zdobyły i zrabowały miasto. W latach 1645-1666 Żory były rządzone przez Wazów, a w 1742 r. po pierwszej wojnie śląskiej stały się częścią państwa pruskiego. W latach 1919-1921 miały miejsce trzy powstania śląskie, w których brali udział również mieszkańcy Żor. W III powstaniu śląskim miasto zostało zajęte przez powstańców w nocy z 2/3 maja $1921 \mathrm{r}$. Po plebiscycie w 1922 r. Żory znalazły się w granicach Polski. W dniu 1 września 1939 miasto zajął Wehrmacht, a w październiku Żory zostały bezpośrednio włączone do III Rzeszy. W mieście utworzono Polenlager nr 95 Sohrau (1942-1945). Przez miasto przeszedł w styczniu 1945 r. marsz śmierci więźniów obozu koncentracyjnego Auschwitz-Birkenau. Od stycznia do marca 1945 r. trwały walki Armii Czerwonej z wojskami niemieckimi o Żory, w czasie których $80 \%$ zabudowy miasta zostało doszczętnie zniszczone. W mieście na uwagę zasługuje Stare Miasto z fragmentami murów obronnych z XIV w., gotycki kościół parafialny pw. św. Apostołów Filipa i Jakuba z XV w. oraz kościół ewangelicko-augsburski z 1931 r. Zob. A. Nowack, Die Stadtpfarrkirche zum heiligen Philippus und Jacobus in Sohrau O/S, Neustadt OS 1900; E. Nerlich, Aus der Geschichte der Stadt Sohrau OS, Dortmund 1972;

5211 listopada (przyp. aut.).

${ }^{53}$ Świeżo lokowanych (przyp. aut.).

${ }^{54}$ Grosze praskie (przyp. aut.).

${ }^{55}$ Wieś zwana po polsku Proszowiec, a po niemiecku Proschowitz.

${ }^{56}$ Wieś zwana po polsku Bojanów, po niemiecku Bojanow (od 1936 r. Kriegsbach), położona W województwie śląskim, w powiecie raciborskim, w gminie Krzanowice. W 1532 r. wieś nosiła nazwę Boyanoff a w 1896 r. Bojanów oraz Bojanow. Po raz pierwszy została wspomniana w dokumencie z 1313 r., w którym wymieniony jest jako świadek rycerz Gerhard z Bojanowa. W nocy 24/25 sierpnia 1683 r. 27.000 żołnierzy króla Jana III Sobieskiego zdążającego na odsiecz Wiednia, biwakowało na rozległych łąkach między Bojanowem a Borucinem. Zob. H. Adamy, Die Schlesischen Ortsnamen ihre entstechung und bedeutung, Breslau 1888, s. 14; K. Damrot, Die älteren 
rami. Natomiast w księstwie opawskim miasteczko Babrouicz ${ }^{57}$ wraz z wójtostwem i mieszkańcami oraz wsiami do niego od dawna należącymi, a mianowicie Dehilau $^{58}$, Ciruenkau $^{59}$, Sulkau $^{60}, \mathrm{z}$ przynależnymi do nich folwarkami, młynami,

Ortsnamen Schlesiens, ihre Entstehung und Bedeutung: mit einem Anhange über die schlesisch-polnischen Personennamen : Beiträge zur schlesischen Geschichte und Volkskunde, Beuthen 1896.

${ }^{57}$ Baborów (dawna nazwa Baworów), niemiecka nazwa Bauerwitz, a czeska Bavorov, miasto w województwie opolskim, w powiecie głubczyckim, siedziba gminy miejsko-wiejskiej Baborów. Leży na Przedgórzu Sudeckim nad rzeką Psiną (w gwarze śląskiej zwanej Cyną). Pierwsza wzmianka pochodzi z $1296 \mathrm{r}$. Wymieniony w nim został wójt baborowski Jarosław (Jeroslaum advocatum de Baurwitz). Miasto powstało jednak w 2. połowie XIII w. Wzmianka o wójcie wskazywać może na lokację na prawie niemieckim. Osobą, która podjąć miała się lokacji był czeski możnowładca Bavor II (przez historię znany także jako Bavor III). W XIV w. miasteczko zostało kupione przez konwent dominikanek w Raciborzu. Kościół parafialny wzmiankowany w 1386 r., powstał najprawdopodobniej w momencie lokacji. W 1405 r. Baborów był już miasteczkiem zarządzanym przez magistrat. W 1750 r. w mieście działały cechy szewców, kuśnierzy, tkaczy i kowali. Dla pełnego rozkwitu miasta decydujące znaczenie miała budowa kolei żelaznej, otwartej w 1856 r. Pod koniec XIX wieku powstały tu cukrownia i cementownia: w 1909 r. otwarto 3 cegielnie, 2 parowe młyny, słodownię, mleczarnię i fabrykę kafli. W Baborowie znajdują się zabytki: zespól zabudowy Starego Miasta, w tym pochodzący z połowy XIX w. i przebudowany w 1922 r. kościół parafialny p.w. Narodzenia NMP, drewniany kościół cmentarny p.w. św. Józefa, barokowy, wzniesiony w $1700 \mathrm{r}$. i ratusz z pocz. XIX w. W Baborowie urodził się Adam Krawarski (1585-1660), który w 1607 r. wstąpił do jezuitów. Podczas rekatolicyzacji Korony Czeskiej nawrócił na katolicyzm około 32.500 osób. Zob. D. Halmer, Kilka uwag o lokalizacji i powstaniu miasta Baborów, w: Europa, Ślask, Świat najmniejszy, red. H. Honysz, J. Mokrosz, Katowice-Rybnik 2007; B. Cimała, S. Senft, Baborów 1296-1996. Dzieje miasta i gminy, Opole 1996; W. Dziewulski, Przeszłość Baborowa (do r. 1945), „Kwartalnik Opolski”, 3 (1958) s. 67-79; A. Tschauder, Kurze Geschichte der Stadt Bauerwitz, Leobschütz 1881; J. Lompa, Krótki rys jeografii Ślaska dla nauki początkowej, Głogówek 1847, s. 33.

${ }^{58}$ Wieś zwana po polsku Dzielów, a po niemiecku Eilgau, położona w województwie opolskim, w powiecie głubczyckim, w gminie Baborów. Nazwa wsi wywodzi się od nazwy określającej dobry udział, podział. Nazwa została później fonetycznie zgermanizowana na Eiglau. W Dzielowie znajduje się zabytkowy, pochodzący z pocz. XVIII w. i przebudowany w XIX w. kościół parafialny pw. św. Mikołaja oraz zabytkowe zagrody z XIX w. Zob. Adamy, Die Schlesischen Ortsnamen, s. 78.

${ }^{59}$ Wieś zwana po polsku Czerwonków, po niemiecku Tschirmkau (w latach 1936-1945 Schirmke) i czesku Červenkov, położona w województwie opolskim, w powiecie głubczyckim, w gminie Baborów.

${ }^{60}$ Wieś zwana po polsku Sułków (staropol. Sulislawicz, do 31 grudnia 2004 - Sulków), a po niemiecku Zilchowitz lub Zülkowitz (w latach 1936-1945 Zinnatal) i po czesku Sulkov. Wieś sołecka, położona jest w województwie opolskim, w powiecie głubczyckim, w gminie Baborów, na lewym brzegu rzeki Psiny. Nazwa miejscowości pochodzi od staropolskiego imienia założyciela Sulisława, tego, który cieszy się lepszą sławą od innych. Najstarsze źródła pisane wspominające miejscowość pochodzą z 1340 r. Dawniej Sułków stanowił własność dominikanek z Raciborza. W 1880 r. wieś funkcjonowała pod nazwą Sulkowice oraz należała do parafii Dzielów. We wsi funkcjonowała dawniej specyficzna forma gwary śląskiej - dialekt sułkowski. Pisał w nim swoje utwory Feliks Steuer, który urodził się w Sułkowie. Do 1905 r. prawie wszyscy mieszkańcy Sułkowa używali wyłącznie gwary języka polskiego, mimo, że księża z Baborowa używali do głoszenia kazań języka morawskiego. Zob. H. Adamy, Die Schlesischen Ortsnamen ihre entstechung und bedeutung, Breslau 1888, s. 8; Słownik geograficzny Królestwa Polskiego i innych krajów stowiańskich, t. 11, red. B. Chlebowski, Warszawa 1880-1914, s. 574; F. Steuer, Dialekt sułkowski, Kraków 1934. 
stawami rybnymi i [z prawem] odławiania ryb, łąkami, pastwiskami, kopalniami i ugorami, lasami, czynszami, mieszkańcami i ich dochodami oraz poszczególnymi użytkami, jakkolwiek zwanymi lub będących nazwanymi. Na wszystkich tych dobrach szlachetna i zakonna dziewica, panna Anna ${ }^{61}$, córka Siemowita, znamienitego księcia mazowieckiego, we wspomnianym klasztorze z nami mieszkająca, wraz z wymienionymi wyżej pannami otrzyma taką samą część [mego spadku]. Podobnie wieś Bescav ${ }^{62}$ z jej wszystkimi przynależnościami, użytkami i powszechnymi należnościami, bez względu na to, na czym one polegają, chcemy przeznaczyć wyłącznie i powierzyć naszym pannom, wspomnianym współmieszkankom, Elżbiecie i Agnieszce. Połowa zaś wsi Suchinczyn ${ }^{63}$ będzie przyznana i należy się samej pannie Elżbiecie, wyżej wspomnianej. Ponadto w powiecie kozielskim wieś zwaną Vczescav ${ }^{64} \mathrm{z}$ folwarkiem Warmuncouicze ${ }^{65} \mathrm{i}$ folwarkiem w Mozerav ${ }^{66} \mathrm{z}$ prawem patronatu czyli kolatorstwa poszczególnych kościołów do nas aktualnie należących i [przez nas] posiadanych. Zastrzegamy wszakże, że jeśli wspomniana panna Anna, znamienita córka księcia mazowieckiego, przeży-

${ }^{61}$ Anna była córką Ziemowita III czerskiego i Eufemii, najstarszej córki Mikołaja II Przemyślidy i Anny, siostry Ofki. Urodziła się w 1345 r., przed 1358 r.wstąpiła do raciborskich dominikanek, u których zmarła w 1403 r. Zob. P. Newerla, Ratibor einst und jetzt, Racibórz 1998, s. 261.

${ }^{62}$ Wieś zwana po polsku Bieszków, a po niemiecku Bieskau, która dziś jest częścią Nowej Cerekwi. W dniu 1 kwietnia 1937 r. Bieszków i Nowa Cerekwia (cz. Nová Cerekev, niem. Deutsch Neukirch) zostały połączone w jedną miejscowość o nazwie Altstett. Po 1945 r. wieś nazwano Nową Cerekwią. Jest ona położona w województwie opolskim, w powiecie głubczyckim, w gminie Kietrz (Katscher).

${ }^{63}$ Wieś zwana po polsku Sucha Psina, po niemiecku Zauchwitz (dawniej Zauchwiz, a w latach 1936-1945 Dreimühlen) i po czesku Suchá Pština, położona w województwie opolskim, w powiecie głubczyckim, w gminie Baborów. Najstarsza nazwa wsi brzmiała: Suchoppina, czyli suche korzenie, kłącze. We wsi znajduje się wzniesiony w 1714 r. kościół parafialny pw. św. Jodoka, przebudowany w XIX w. Parafia należała pierwotnie do diecezji ołomunieckiej, znajdując się na terenie tzw. dystryktu kietrzańskiego, który do diecezji opolskiej został włączony w 1972. Zob. H. Adamy, Die Schlesischen Ortsnamen, s. 42; G. Wolný, Kirchliche Topographie von Mähren, t 5. Brünn 1863, s. 246-249.

${ }^{64}$ Wieś zwana po polsku Ucieszków a po niemiecku Autischkau, położona w województwie opolskim, w powiecie kędzierzyńsko-kozielskim, w gminie Pawłowiczki (Pawlowitzke, w latach 1936-1945 Gnadenfeld). Najstarsze znane informacje o kościele w Ucieszkowie pochodzą z $1358 \mathrm{r}$. W 1805 r. wybudowano nową, klasycystyczną świątynię pw. Opatrzności Boskiej. W miejscowości znajduje się także (przy ul. Klasztornej 8) dom zakonny sióstr elżbietanek (z 1910 r.).

${ }^{65}$ Część wsi Pawłowiczki (w województwie opolskim, w powiecie kędzierzyńsko-kozielskim, w gminie Pawłowiczki); przyłaczona wieś zwana po polsku Warmuntowice i po niemiecku Warmuntowitz (w latach 1936-1945 Niedersteine).

${ }^{66}$ Wieś zwana po polsku Modzurów, a po niemiecku Mosurau, położona w powiecie raciborskim, w gminie Rudnik. Pierwszy raz wzmiankowana w 1274 r. W 1475 r. w Statuta Synodalia Episcoporum Wratislaviensium wymieniona jest jako Modzeraw. Wieś nosiła niemiecką nazwę Mosern, od słowa Mosurau, które oznacza miejsce mokre i bagniste. We wsi stoi wzniesiony w latach 1896-1897 neogotycki kościół parafialny pw. Trójcy Świętej oraz neogotycki, pałac von Königów z 1864 r. Zob. G. Wawoczny, Zabytki powiatu raciborskiego, s. 102; A. Bindacz, Gmina Rudnikkraina pałaców i zieleni, Racibórz 2005, s. 28; F.X. Seppelt, Die Breslauer Diözesansynode vom Jahre 1446, Breslau 1912, s. 97. 
je Elżbietę i Agnieszkę, wspomniane panny, wspomniana połowa wsi przejdzie na Annę, która stanie się prawną posiadaczką wszystkich wymienionych dóbr, z wyjątkiem czterech wsi wcześniej wymienionych, po drugiej stronie Odry leżących, które wtedy ze wszystkimi przynależnościami, dochodami i użytkami natychmiast przejdą na własność naszego konwentu sióstr, czyli panien z klasztoru. Prócz tego zarządzamy, wyrażamy wolę, rozporządzamy i legujemy, że z dochodów wsi Vczescav ${ }^{67}$ braciom zakonu kaznodziejskiego z klasztoru raciborskiego ma być wypłacanych 10 grzywien polskich zamiast piwa, ze względu na liczbę i zapłatę za msze święte $\mathrm{w}$ intencji wymienionego klasztoru panien i sióstr, $\mathrm{z}$ której to kwoty przeor pomienionego klasztoru, będący obecnie lub w przyszłości, winien i jest zobowiązany przekazywać każdego dnia czterem braciom. $Z$ ochotą nadmieniamy także, że jeśli książę Jan, syn wspomnianego pana Mikołaja i pani Anny, świętej pamięci siostry naszej, będzie miał kiedyś córkę spłodzoną przez siebie zgodnie $\mathrm{z}$ prawem i przeznaczy ją także do naszego zakonu i konwentu w wymienionym wcześniej klasztorze, ona również wraz z panną Anną, córką wymienionego księcia mazowieckiego, wszystkie im zapisane rzeczy i każde z osobna będą miały w swym ręku, będą je posiadały i nimi zarządzały. Dlatego obiecujemy z całkowitą szczerością, że z tej naszej donacji, zapisu spadkowego i dobrowolnego zrzeczenia się, dokonanego, zarządzonego i rozporządzonego w odniesieniu do wszystkich wspomnianych dóbr, ani za życia, ani w chwili śmierci nie odwołamy czy w jakiś inny sposób nie zmienimy pod wpływem czyjejś namowy i niewdzięczności lub podstępnej wiadomości. Natomiast uprzedza się, że gdyby panny, godnie powyżej wspomniane z imienia, już nie żyły, wszystkie dobra wcześniej opisane i odczytane mają należeć po wieczne czasy i być rozwijane [jako dobra] konwentu sióstr i panien we wspomnianym klasztorze raciborskim, bez jakiejkolwiek przeszkody, sprzeciwu i odmowy. Ponadto pragniemy, aby także z racji pobieranych dochodów oraz naszej darowizny siostry wieczyście przebywające $\mathrm{w}$ tymże klasztorze razem modliły się za dusze moich rodziców, a szczególnie niech zawsze odmawiają akty strzeliste za mego brata, najjaśniejszego Leszka, dobrze w naszej pamięci wspominanego. Natomiast najznakomitszy pan Mikołaj książę pan opawski i raciborski, wraz z panen Janem ${ }^{68}$, synem

${ }^{67}$ Ucieszków.

${ }^{68}$ Jan I (Hanusz) raciborski (1332-1380/1382), był najstarszym synem księcia opawskiego i raciborskiego Mikołaja II Przemyślidy i Anny Piastówny raciborskiej. Urodził się około 1332 r. Doświadczenie polityczne zdobywał na dworze Karola IV Luksemburskiego w Pradze. W 1361 r. za jego radą pojął za żonę księżniczkę żagańską Annę Piastównę. Po śmierci ojca w 1365 r., jako książę opawski, karniowski i raciborski był do 1377 r. opiekunem młodszego przyrodniego rodzeństwa (Mikołaja III, Wacława i Przemka). Jan potwierdził prawa magdeburskiego miastu Opawie w 1372. W 1377 pod naciskiem wielmożów i młodszych braci Jan zdecydował się na podział ojcowizny, w wyniku którego w jego rękach pozostał Racibórz, Bruntal i Karniów. Wcześniej bo jeszcze w 1375 w związku z kłopotami finansowymi, Jan odsprzedał księciu opolskiemu Władysławowi okręgi Pszczyny i Mikołowa. W 1378 z tych samych powodów zastawił księciu cieszyńskiemu Przemysławowi Noszakowi miasteczko Żory. Z małżeństwa z Anną żagańską, córką Henryka V Żelaznego, Jan I doczekał się dwóch synów: Jana II Żelaznego i Mikołaja IV, oraz córki Małgorzaty (†1407), wydanej za księcia cieszyńskiego Bolesława I. Nie wiadomo kiedy Jan I dokładnie zmarł. Nastąpiło 
wspomnianego księcia i pana, na tę naszą darowiznę, zapis spadkowy i zrzeczenie się [wymienionych dóbr] wyrazili pełną zgodę i jako dobry uczynek dodali przyzwolenie jak najchętniej, uważając [tę darowiznę] za uczynioną słusznie, prawomocnie i łaskawie, zatwierdzając wszystko w szczegółach i w całość swoim autorytetem i pełnią władzy. Aby zaś wszystko powyżej przytoczone i wyrażone nabrało mocy na przyszłość, kazaliśmy ten dokument spisać i opatrzyć naszymi pieczęciami, za wiedzą, z polecenia, w obecności i z przyzwolenia wymienionych dostojnych książąt i władców, rozkazaliśmy i postaraliśmy się zabezpieczeniem wzmocnić. Dano we wspomnianym klasztorze znajdującym się w mieście Raciborzu, roku Pańskiego 1358 w sobotę ${ }^{69}$ po św. Mikołaju, biskupie i wyznawcy, w obecności często wymienionych książąt i panów, pana Mikołaja i jego syna Jana, księcia wcześniej wymienionego, Henryka zwanego Hoberk, rycerza, zakonnych mężów, brata Piotra, prowincjała prowincji polskiej, brata Jana, spowiednika sióstr i panien zakonu kaznodziejskiego św. Dominika, Piotra niegdyś Gotfrydowego, rektora kościoła św. Mikołaja przed bramami Raciborza, publicznego notariusza, który także spisał treść naszego wyżej wymienionego legatu, darowizny i rezygnacji, prośby i dobrej woli oraz sporządził instrument publiczny ${ }^{70}$, a także [w obecności] wielu innych świadków. I przez ręce ${ }^{71}$ Franciszka, plebana w Greczu ${ }^{72}$ koło Opawy, w diecezji ołomunieckiej protonotariusza wspomnianego

to pomiędzy 16 lutego 1380 a 28 października 1382 r. Pochowany zaś został w klasztorze dominikanek w Raciborzu.

${ }^{69} 8$ grudnia (przyp. aut.).

${ }^{70}$ Dokument (przyp. aut.).

${ }^{71}$ Dokument napisał na pergaminie (przyp. aut.).

${ }^{72}$ Grodziec nad Morawicą, po niemiecku Grätz, po czesku Hradec nad Moravicí, miasto w Czechach, położone w kraju morawsko-śląskim. W Grodźcu bądź jego bliskiej okolicy spotkali się w 965 r. posłowie weselni polskiego księcia Mieszka z Dąbrówką, córką czeskiego księcia Bolesława I. W latach 990-1032 gród należał do państwa Bolesława Chrobrego i Mieszka II. Pierwsza historyczna wzmianka o umocnionym grodzie z załogą wojskową czeskiego księcia pochodzi z 1060 r., kiedy to pod jego murami zostało pokonane wojsko polskiego króla Bolesława II Śmiałego. Jego przynależność do państwa czeskiego utrwaliła się w XII wieku po zawarciu pokoju kłodzkiego. W drugiej połowie XIII wieku król czeski Przemysł II Ottokar w miejscu dotychczasowego grodu postawił gotycki zamek i w nim schroniła się wdowa królowa Kunegunda. Zamek był świadkiem jej legendarnego romansu z Zawiszą z Falkensteinu. W 1481 r. książę Wiktoryn z Podiebradów nadał Grodźcowi prawa miejskie. W 1584 r. cesarz Rudolf II sprzedał tutejsze dobra ziemskie Kaszparowi Pruskowskiemu z Pruskowa. W 1733 r. dobra przeszły w ręce Neffzernów, a w latach 1778-1945 pozostawały w rękach książąt Lichnowskich. W czasie wojny trzydziestoletniej miasto i zamek zdobywały na przemian wojska cesarskie i protestanckie. Grodziec mocno wtedy ucierpiał i stał się wioską. Prawa miejskie odzyskał dopiero w 1702 r. Największy wpływ na historię zamku i miasta miał ród książąt Lichnowskich. W każdej generacji książęta byli znakomicie wykształceni i pozostawali mecenasami kultury i sztuki. Obok władców, dygnitarzy dworów europejskich, arystokracji, naukowców i historyków sztuki tutejszy zamek gościł również wiele osobistości świata kultury. Na początku XIX w. przebywali tu: Ludwig van Beethoven, Nicolo Paganini i Ferenc Liszt. Lichnowscy utrzymywał przyjacielskie stosunki z Wolfgangiem Amadeuszem Mozartem i naukowcem Aleksandrem von Humboldt. Na przełomie XIX i XX w. Grodziec muzyczny został zastąpiony Grodźcem literackim. Przebywali tu: Cosima Wagner, żona Ryszarda Wagnera i córka Ferenca Liszta, prozaik Gerhard Hauptmann, pisarz i autor librett Hugo von Hoffmannstahl oraz autor dramatów 
znakomitego pana Mikołaja, księcia opawskiego i raciborskiego, mojego ukochanego siostrzeńca na świadectwo wszystkich spraw wyżej przedstawionych.

L.

1358. Dec.[embris] 8.

Nos Eufemia quondam Illustris Principis ac domini Przemislij Ducis Rathouorie filia, Priorissa Claustri seu Monasterij Virginum et Sororum in Civitate Rathouoriensi fatemur et recognoscimus presentibus universis, Quod maturo consilio prehabito mentis et bone racionis compos, de bonis nobilis a deo concessis et a progenitoribus nostri rite et racionaliter devolutis tale facimus testamentum. Primo et principaliter legamus damus ordinamus assignamus et irrevocabiliter resignamus Nobilibus pueris filiabus quondam Sororis nostre Inclite domine Anne, Consortis Serenissimi Principis et domini, domini Nicolai Oppauie et Rathouorie ducis ex ipso progenitis, domicellabus Elizabeth et Agnes nobiscum in dicto nostro claustro degentibus, Universaliter omnia et singulariter singula nostra bona, quocunque nomine censeantur aut in quibuscunque rebus consistunt, Jure proprietatis ad nos pertinencia. Primo in terra Rathouoriensi, ex illa parte fluminis que Odra vulgariter dicitur has iacentes quatuor villas, videlicet Liski, Pogrebine, Luboma, Marcouicze cum Allodijs Molendinis piscinis piscibus et piscacionibus, pratis silvis nemoribus rubetis et cum universis pertinencijs et appendijs suis. Item in Civitate Sarensi de decem Bancis carnium de quoliber quintus dimidius lapis fusi et mundi sepi omni anno in festo beati Martini cedent. Item in Civitate Rathouor a quolibet Pannicida unam Marcam Polonicalem omni anno in festo beati Galli recipient. Item de qualibet Instita octo scoti in iam dicto festo. Pretera de quolibet laneo ante Civitatem Rathouoriensem sito sex scoti pro annuo censu debentur. Item omni anno de Novis ortis adiacentibus Civitati Rath. Novem Marcas Polonicales et novem Scotos. Item de domibus in lata platea et decinis (sic!) in fossato situatis una Sexagena grossorum veri census cum omnibus que continentur in Prosuinkel. Super hec omnia damus et adiungimus eciam villam Bougnou cum allodio et attinencijs, usufructibus et appendijs universis. In ducatu vero Oppauiensi, oppidum Babrouicz cum Advocacia et Oppidanis, Et hijs villis ad hoc ab antiquo pertinentibus, videlicet Dehilau, Ciruenkau, Sulkau, cum singulis allodijs, molendinis, piscinis, piscacionibus, pratis, rubetis, montibus, planis, silvis, censu, hominibus et proventibus ac singulis utilitatibus quocumque vocentur nomine et poterint inveniri. In omnibus autem bonispredictis Nobilis ac Religiosa virgo domicella Anna filia domini Semouiti ducis Mazouie Illustris in

i krytyk literacki Karl Kraus. Lichnowscy prowadzili ożywioną korespondencję z Reinerem Maria Rilke, Markiem Twainem, Pablo Picasso i Oskarem Kokoschką. W czasie panowania Lichnowvskich Grodziec przeżywał dobrobyt gospodarczy. W XIX w. wzniesiono przędzalnię, hutę żelaza, browar książęcy, młyny i fabrykę papieru. Na początku 1945 r. przeszedł przez miasto marsz śmierci sowieckich jeńców wojennych. Po II wojnie światowej Grodziec był nazywany Hradcem koło Opawy. W 1968 r. wrócił do pierwotnej nazwy Hradec nad Moravicí, a w 1971 r. odzyskał prawa miejskie. 
prefato Claustro nobiscum degens cum antedictis domicellabus omnino equalem partem obtinebit. Item villam Bescav cum suis omnibus pertinencijs, utilitatibus et appendijs universis in quibuscum rebus consistunt, volumus solis virginibus domicellabus predictis Elizabeth et Agnethe dirivari penitus et deberi. Dimidia autem pars ville Suchinczyn soli domicelle Elizabeth predicte assignabitur et debetur. Insuper in districtu Coslensi villam dictam Vczescav cum allodio Warmuncouicze et allodio in Mozerav cum Jure patronatus seu collacionibus singularum Ecclesiarum ad nos dudum pertinentibus et obtentis. Tali condicione adiecta, si domicella Anna nata prenominati domini duci Mazouie Illustris supervixerit Elizabeth et Agnethe domicellabus prefatis sublatis de medio, antedicta Anna omnia premissa tenebit ac libere possidebit, Exceptis quatour villis priusnominatis ab alia parte fluminis Odre iacentibus et situatis, que tunc cum omnibus suis pertinencijs proventibus et utilitatibus ad Conventum Sororum at virginum in predictum Claustrum et Monasterium quantocius devolventur. Preterea ordinamus volumus disponimus et legamus, quod de perceptis in villa vcescav fratribus ordinis Predicatorum in Rathouoriensi claustro pro brasio dari debentur et assignari decem Marce polonicalis numeri et pagamenti Respectu quarum Prior iamdicti Claustri qui est pronunc vel fuerit infuturum, debet et tenetur omni die Monasterium predictarum virginum ac sororum pro dicendis Missis ibidem transmittere quatuor fratres. Addicimus eciam omnino volentes, Si dominus Johannes dux filuis antedicti domini Nicolay et domine Anne Sororis nostre pie recordacionis umquam filiam procreatam ex se legittime generaverit, ipsam quoque nostro ordini religioni et Conventui in antedictum Claustrum tradiderit, Illa cum predicta domicella Anna predicti ducis Mazouie fila, omnia et singula ipsis prescripta tenebit, gubernabit ac eciam possidebit. Quamobrem promittimus bona nostra sincera fide hanc nostram donacionem, legacionem et liberam resignacionem in omnibus premissis factam, ordinatam et dispositam nullius suggestionis et ingratitudinis causa seu alicuius informacionis sinistre in vita vel in morte contraire seu aliqualiter revocare. Singulis autem domicellabus nominaliter et luculenter superius expressis non existentibus Omnia prius expressa et recitata, ut premittitur, ad Conventum sororum ac virginum in antedicto claustro in Rathouor perhenniter debent pertinere et devolvi, nullo umquam inpediente, contradicente seu aliqualiter refragrante. Insuper volumus ut deinceps de perceptis hijs sublevamentis et nostris donacionibus dicte Sorores inperpetuum in ipso claustro degentes iugiter orent pro animabus parentum nostrorum et specialiter fratris nostri Illustris Lesconis bone memorie nostreque semper exerceant pios actus. Hanc autem donacionem, legacionem et resignacionem nostram Excellentissimus Princeps et dominus dominus Nicolaus Oppauie et Rathouorie dux, Inclitus quoque dominus Johannes filius dicti domini ducis, consensum plenum et operam bone voluntatis addunt, dederunt et assensum benivolum et benignum, Rata firma et grata habentes omnia et singula prelibata, plenavauctoritate ac potestate debita confirmantes. Ut autem hec premissa et omnia expressa superius robur obtineant perpetue firmitatis, presentes litteras scribi fecimus et nostri Sigilli ac Sigillis premissorum Illustrium Principum et dominorum scitu, mandatu, presencia et beneplacito, iussimus et providimus munimine roborari. Date in antedicto claustro Sito in Civitate Rathouoriensi, Anno 
domini Millesimo Trecentesimo Quinquagesimo octavo Proxima Sabbato post festum beati Nicolai Episcopi et Confessoris, In presencia sepedictorum Principum et dominorum, domini Nicolai et eiusdem filij domini Johannis ducis priusdicti, Heynrici dicti Hoberk Militis, Religiosi viri fratris Petri provincialis provincie Polonie, fratris Johannis confessoris virginum et sororum predictarum ordinis Predicatorum beati Dominici, Petri quondam Gotfridi, Rectoris Ecclesie beati Nicolay ante fores Civitatis Rathouoriensis, publicu Notarij, qui eciam super hac nostra premissa legacione, donacione et resignacione, peticione et bona voluntate nostra prehabita scripsit et confecit instrumentum publicum, et alijs pluribus fide dignis. Et per manus Franczisci Plebani in Grecz prope Oppauiam Olomucensis dyocesis Prothonotarij prenominati Incliti Principis domini Nicolai Oppauie et Rathouorie ducis, Sororij nostri karissimi, in Testimonium omnium premisorum.

$* * * *$

Codex Diplomaticus Silesiae, wyd. W. Wattenchbach, t. II, Urcunden der Dominikaner und Dominikanerinnen in der Stadt Ratibor, Breslau 1892, s. 159160.

W imię Pańskie amen. Tegoż roku 1358, w indykcję XXII, w szósty dzień przed nonami grudniowymi, w godzinach wieczornych. W klasztorze sióstr w Raciborzu, w diecezji wrocławskiej, w ich specjalnym pomieszczeniu mieszkalnym, szlachetnie urodzona panna zakonna, panna Eufemia, córka niegdyś Przemysła, księcia raciborskiego, tegoż klasztoru przeorysza, w obecności mojej, jako notariusza, i niżej wymienionych świadków, będąca w pełni władz umysłowych, wyraziła się w takich słowach i otwarcie powiedziała: Dajemy, przyznajemy i nieodwołalnie zrzekamy się i zapisujemy córkom najjaśniejszego pana Mikołaja, księcia ziemi opawskiej i raciborskiej, oraz jego małżonki Anny, naszym siostrzenicom, mianowicie pannom Elżbiecie i Agnieszce, ze mną mieszkającym, zasadniczo i przede wszystkim całkowicie wszystkie, a szczególnie pojedyncze nasze dobra, gdziekolwiek występują nominalnie, należące do nas i do naszej własności. Po pierwsze, leżące na terytorium raciborskim, od strony rzeki Odry, cztery wsie, a mianowicie Liski ${ }^{73}$, Pogrebine ${ }^{74}$, Marcouice ${ }^{75}$, Luboma ${ }^{76}$, $\mathrm{z}$ folwarkami, młynami, stawami i rybami w nich się znajdującymi, z łąkami, lasami, zagajnikami, ze wszystkimi ich przynależnościami. W mieście Zarensis ${ }^{77}$ od dziesięciu jatek od

\footnotetext{
${ }^{73}$ Lyski.

${ }^{74}$ Pogrzebień.

${ }^{75}$ Markowice, dziś część Raciborza.

${ }^{76}$ Lubomia.

${ }^{77}$ Żory.
} 
każdej półpięta kamienia lanego i czystego łoju, każdego roku na św. Marcina ${ }^{78}$ [uiszczany]. W Raciborzu każdy sukiennik ma płacić jedną grzywnę groszy praskich co roku na świętego Gawła według rachuby polskiej. Podobnie od każdego straganu osiem skojców. Poza tym od każdej zagrody leżącej przed Raciborzem należy się roczny czynsz sześciu skojców. Roczna opłata od nowych osiedli położonych przy mieście sięga dziewięciu grzywien polskich i dziewięciu skojców. Od domów na ulicy Szerokiej i dworów znajdujących się na grobli (sic!) rzeczywisty czynsz jednej grzywny groszy ${ }^{79}$. Przydzielamy także te [czynsze obowiązujące] w Proswinkel ${ }^{80}$ wraz ze wszystkimi, do których się odnoszą. Poza tym wieś Bognav $^{81} \mathrm{z}$ folwarkiem i wszelkimi użytkami. Baurouicz ${ }^{82} \mathrm{w}$ księstwie opawskim z mieszkańcami i tymi wsiami, które od dawna do niego należą, $\mathrm{z}$ wójtostwem Dehylav ${ }^{83}$, Ciruencav ${ }^{84}$, Sulkov $^{85}$ z folwarkami, młynami, stawami, łąkami, zagajnikami i ze wszystkimi przychodami. Panna Anna, panna zakonna, córka księcia mazowieckiego, żyjąca w tymże klasztorze, będzie miała równą część na tych dobrach, jak wymienione panny zakonne. Wieś Bescav ${ }^{86}$ również należy się pannom Elżbiecie i Agnieszce, ale połowa wsi Suchincin ${ }^{87}$ należy się tylko Elżbiecie. Co się tyczy wsi w powiecie kozielskim, a mianowicie Wescav ${ }^{88} \mathrm{z}$ folwarkiem Warmuntouicz ${ }^{89} \mathrm{i}$ folwarkiem Mozorav ${ }^{90}$, a także $\mathrm{z}$ beneficjami kościelnym i prawem patronatu do nas należącymi od warunkiem, że panna Anna, córka wspomnianego księcia Siemowita, będzie żyła, ale po śmierci Elżbiety i Agnieszki cała [moja] darowizna przejdzie na jej własność, z wyjątkiem owych czterech wsi, leżących o drugiej stronie Odry; te zaś ze wszystkimi swoimi przynależnościami przekazane zostaną Konwentowi świętych mniszek. Postanawiamy także, iż z dochodów wymienionej wsi Wescav ${ }^{11}$ należy się dziesięć grzywien polskich braciom z zakonu braci kaznodziejów ${ }^{92}$ za jęczmień. Mając to na względzie przeor klasztoru raciborskiego, aktualnie sprawujący tę funkcję jest zobowiązany przysyłać do klasztoru sióstr raciborskich czterech kapłanów celu odprawiania u nich codziennych mszy świętych. Dopowiadamy jeszcze, że jeśli książę Jan, syn naszej siostry, będzie miał córkę z prawego łoża i przeznaczy ją do naszego zakonu i konwentu, ta wraz ze współmieszkanką panną Anną, córką księcia mazowieckiego, będzie zarządzała wszystkimi dobrami im zapisanymi. Obiecujemy z całkowitą

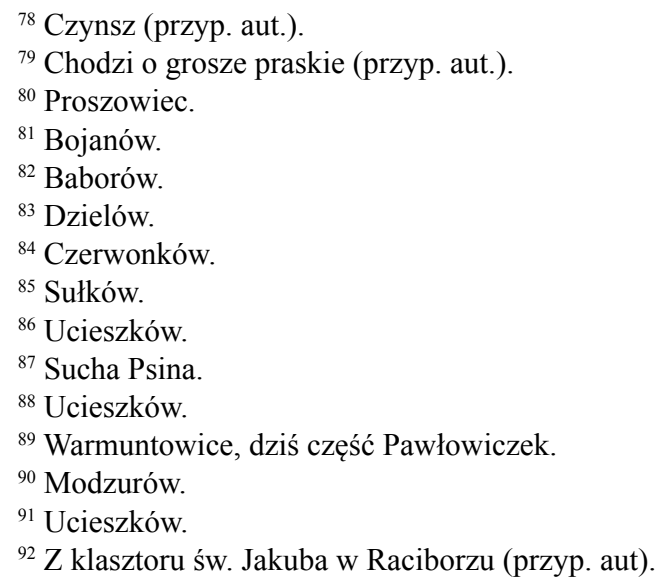


szczerością, że tej naszej darowizny i dobrowolnego zrzeczenia się wszystkiego, ani na skutek czyjejś złej woli, ani [z uwagi] na donos, za życia czy w chwili śmierci, w jakikolwiek sposób nie odwołamy. Natomiast uprzedza się, że gdyby panny zakonne, godnie powyżej wspomniane z imienia, już nie żyły, wszystkie dobra wcześniej opisane i odczytane mają należeć po wieczne czasy i być rozwijane [jako dobra] konwentu świętych mniszek we wspomnianym klasztorze raciborskim, bez jakiejkolwiek przeszkody. Na koniec pragniemy, aby [siostry za otrzymywane] dochody odmawiały akty strzeliste za dusze naszych rodziców oraz brata Leszka i naszą. Na tę darowiznę i zapis spadkowy zgodnie zezwolili najjaśniejszy książę i pan Mikołaj, władca ziemi opawskiej i raciborskiej wraz z synem, księciem Janem. Aby zaś to wszystko nabrało mocy prawnej, poleciła ten dokument spisać i umocnić pieczęcią swoją i pieczęciami wymienionych książąt i panów. Działo się i dano w roku, indykcji, miesiącu, dniu, godzinie, miejscu jak wyżej, w obecności tych książąt i panów, [a mianowicie] Mikołaja, księcia wspomnianych ziem i jego syna Jana, rycerza Henryka Hoberga, brata Piotra, prowincjała prowincji polskiej, brata Jana, spowiednika wymienionego klasztoru oraz wielu innych wiarogodnych [świadków].

A ja Piotr, syn Gotfryda z Raciborza, kapłan diecezji wrocławskiej, notariusz publiczny z nominacji cesarskiej, w tej darowiźnie, zapisie spadkowym i testamencie tak uczynionym przez siostrę Eufemię brałem udział wraz z wymienionymi świadkami i nadawszy jej [tzn. darowiźnie] publiczną formę dokumentu swoim imieniem i zwyczajowym znakiem opatrzyłem na świadectwo spraw wyżej wymienionych.

(znak notariusza)

LI. 1358. Dec.[embris] 8.

In nomine domini Amen. Sub anno eiusdem Millesimo Trecentesimo Quinquagesimo octavo Indiccione $\mathrm{xxij}^{\mathrm{a}}$. $\mathrm{Vj}^{\mathrm{o}}$. Nonas Decembrum (sic!) Hora quasi vesperarum. In Claustro Sororum in Rathibor In stuba et comodo ipsarum speciali Wrat. Dyoc. Nobilis et Religiosa virgo domicela Evfemia olim Premislij Ducis Rathiboriemsis filia eiusdem Monasterij priorissa In mei Notarij et Testium subscriptorum presencia, mentis et racionis proprie compos, hec verba protulit et aperte dixit: Nos damus assignamus et irrevocabiliter resignamus et legamus pueris filiabus Serenissimij Principis et domini Nycolai Oppauensis et Rathiboriensis Terrarum Ducis et Anne coniugis sue, sororijs nostre (sic!) videlicet virginibus Elizabeth et Angneti nobiscum degentibus principaliter et pre omnibus universaliter omnia et singulaliter singula nostra bona quocumque sententur (sic!) ex nomine, ad nos et ad proprietatem nostram pertinencia, Primo in Territorio Rathiboriensi ab illa par- 
te Odre iacentes, quatuor villas, videlicet Liski ${ }^{93}$, Pogrebine ${ }^{94}$, Marcouice ${ }^{95}, \mathrm{Lu}-$ boma $^{96}$, Cum Allodijs, Molendinis, Piscinis et piscibus in eidem contentis, Pratis, Silvis, Rubetis, cum ipsarum pertinencijs universis. In Civitate Zarensi ${ }^{97}$ de decem Bancis Carnium de quolibet quintum dimidium lapidem fusi et mundi Sepi in festo beati Martini quolibet anno. In Civitate Rathibor Pannicidarum quilibet unam Marcam grossorum pragensium tenetur dare quolibet anno in festo Sancti Galli numeri polonici. De qualibet Instita octo scoti debentur quolibet anno in iam dicto festo. Preterea de quolibet manso ante Civitatem Rathibor iacente sex scoti debentur annuj census. Solucio Novorum ortorum Civitati adiacencium que se extendit ad novem Marcas polonicales et novem scotos singula annuum revolucione. De domibus in lataplatea et de Curijs in foscato (sic!) situatis una sexagena grossorum veri census. Atribuimus eciam illos in Proswinkel cum omnibus quibus tenentur. Nichilominus villam Bognav ${ }^{98}$ cum Allodio et usufructibus universis. In Ducatu autem Oppauiensi Baurouicz cum opidanis et hijs villis illo ab antiquo pertinentibus cum Advocacia scilicet Dehylav ${ }^{99}$, Ciruencav ${ }^{100}$, Sulkov ${ }^{101}$, Cum Allodijs, Molendinis, Piscinis, Pratis, Rubetis et proventibus universis. In hijs bonis Religiosa virgo domicella Anna filia Ducis Mazouie nobiscum in Claustro degens cum predictis domicellabus equalem habebit partem. Item villa Bescav domicellabus Elizabet et Angneti solis debetur, Sed dimidia pars Suchincin ville Elizabet soli debetur. In Districtu Koslensi villam dictam Wcescav ${ }^{102}$ cum Allosio Warmuntouicz ${ }^{103}$ Et allodio in Mozorav ${ }^{104}$, cumque collacionibus Ecclesiarum et Jure patrontus ad nos pertinentibus, Tali adita condicione: Si Anna predicti Ducis Semouiti filia vixerit, Elizabet et Angnete predictis sublatis ab hac luce, omnia possedebit, Exceptis predictis quatuor villis ab illa parte odre iacentibus; ille cum omnibus pertinencijs suis ad Conventum sanctimonialium mox revolventur. Statuius eciam quod de per[cep]tis Wescav ${ }^{105}$ ville predicte fratribus de Ordine fratrum Predictorum pro Brasio debentur dari decem Marce polonicales respectu quarum Prior Claustri Rathibor qui pro tempore fuerit, tenetur mittere ad claustrum pro dicendis missis sororum in Rathibor quatuor fratres omni die. Adicimus eciam si Dux Johannes filius sororis nostre aliquam filiam legittime generaverit et illam Religioni nostre et Conventui tradiderit, illa cum predicta Anna domicella Mazouie Ducis filia omnia ipsis prescripta gubernavit. Promittimus nostra bona fide

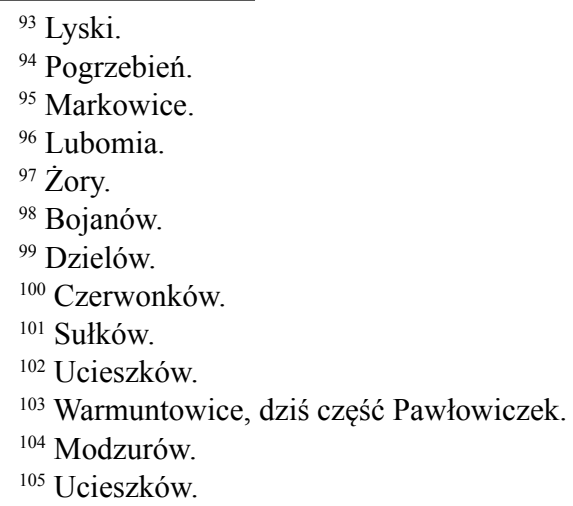


hanc donacionem nostram et liberam resignacionem in omnibus factam non causa alicuius ingratitudinis aut sinistre informacionis in vita vel in morte aliqualiter revocare. Omnibus autem domicellabus luculenter et nominaliter expressatarum (sic!) extinctis, omnia superius recitata ut est premissum ad Conventum sanctimonialium in Rathibor debent revolvi nullo penitus refragrante. Ultimo volumus ut de perceptis pro animabus parentum nostrorum et fratris Lestkonis nostraque ipsos exerceant actus. Huic donacionj et legacionj Excellentissimus princeps et dominus Nycolaus Oppauensis et Rathiboriensis Terrarum Dux cum Duce Johanne filio adididit (sic!) consensum. Ut autem hec omnia robur obtinenat firmitatis, presentes scribi et Sigilli sui munimine et Sigillorum predictorum principum et dominorum mandavit Roborari. Actum et Datum Anno Indiccione mense die hora loco quibus supra, Presentibus hijs principibus et dominis, Nycolao predictarum Terrarum Duci et Johanne filio suo, domino Henrico Hoberg Milite, Religioso voro fratre Petro Provinciali Polonie, fratre Johanne Confessore predicti Claustri et alijs multis fidedignis.

Et ego Petrus quondam Gotfridi de Rathibor presbiter Wrat. Dyoc. Publicus Imperiali auctoritate Notarius huic donacionj legacionj et Testamento sic facto per domicellam Evfemiam una cum prescriptis testibus presentes interfui et eam in hanc publicam formam redigens meo nomine et signo solito consignavi in Testimonium omnium permissorum.

\section{(Signum Notarii)}

Słowa kluczowe: Ofka Piastówna; testament; przeorysza; mniszki dominikańskie; Racibórz

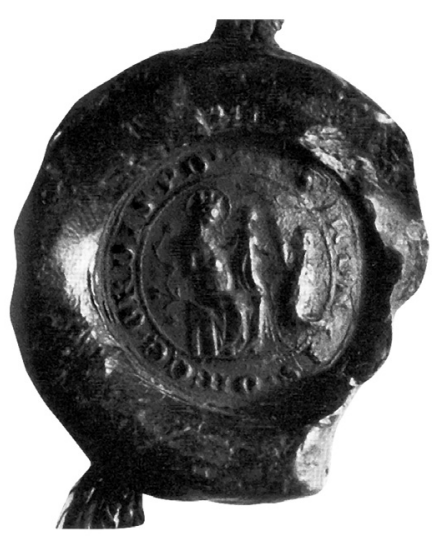

Fot. 1. Pieczęć Ofki z 1358 r. Fot. sprzed 1945 r. Zb. Norberta Miki z Raciborza.

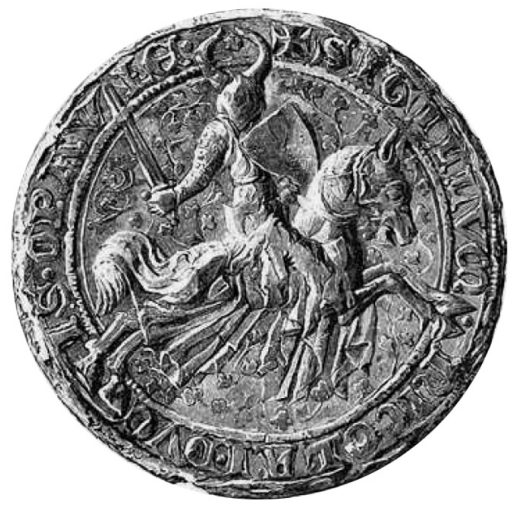

Fot. 2. Pieczęć Mikołaja II z 1358 r. Dziewiętnastowieczny przerys. 


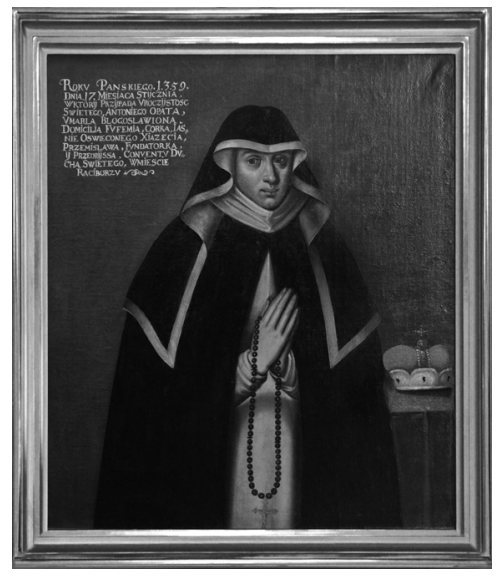

Fot. 3. Obraz Ofki z 1623 r.

Kościół na Gródku w Krakowie.

\section{BIBLIOGRAFIA}

\section{Źródła rękopiśmienne}

Archiwum Archidiecezjalne we Wrocławiu

Rps., sygn. VI B 2a, General-Tableau über sämmtlich eingezogenes Stifts-, Kirchen-, Fundationsvermögen und Ertrag der Stifter und Klöster in Schlesien

Archiwum Państwowe we Wrocławiu

Rep. 135, sygn. 582, Das Leben der Hochseeligen Jungfrau Euphemiae Domicillae, des Herzog Premislai Lesconis Tochter, und Fundatricis des Jungfräuliches Klosters Beym Heyligen Geist in Rattibor, Ord. S. Dominici Beschreiben von Miechovio und Bzovio Pohlnischen Authoribus in Chronica ad Annum 1359

\section{Źródła drukowane}

Codex diplomaticus Minoris Poloniae, red. F. Piekosiński, t. 3, nr 76, Kraków 1876-1905. Codex Diplomaticus Silesiae, wyd. Wilhelm. Wattenchbach, t. II, Urcunden der Dominikaner und Dominikanerinnen in der Stadt Ratibor, Breslau 1892.

Liber albus confraternitatis in ecclesia collegiata Rattiboriae sub titulo Gloriosa Virginis Mariae in Coelos Assumptae, w: Schaffer Hermann, Geschichte einer schlesischen Liebfrauengilde seit dem Jahre 1343, Ratibor 1883.

Peregrini de Opole, Sermones de tempore et de sanctis, wyd. R. Tatarzyński, Warszawa 1997.

Propago D. Hyacinthi Thravmaturgi Poloni seu De rebus praeclare gestis in Prouincia Poloniae Ordinis Praedicatorum. Commentarius. F. Abraham Bzovii Sacrae Theologiae Magistrii, Ord. Praedic., Venetiis 1606, s. 48-49. 


\section{Opracowania}

Adamy Heinrich, Die Schlesischen Ortsnamen ihre Entschetung und Bedeutung, Breslau 1888.

Ballestrem Hyazintha, Eine Perle des Schlesierlandes, „Deutscher Hausschatz“, 31 (1905) nr 22, s. 704.

Barciak Antoni, Eufemia (1299/1301-1359), w: Książęta i księżne Górnego Śląska, red. Antoni Barciak, Katowice 1995, s. 41-42.

Bażan Pius Maria, Eufemia von Ratibor. Blume aus dem Garten des hl. Dominikus im Rufe der Heiligkeit gestorben am 17. Januar 1359. Ein Lebens- und Zeitbild, Vechta 1936.

Bazydło Janusz, Eufemia, Ofka Piastówna, Domicella, w: Encyklopedia katolicka, t. 4, Lublin 1985, kol. 1287-1288.

Bindacz Anna, Gmina Rudnik - kraina pałaców i zieleni, Racibórz 2005.

Capsky Martin, Historia Górnego Śląska. Polityka, gospodarka i kultura europejskiego regionu, Opava 2011.

Cimała Bogdan, Senft Stanisław, Baborów 1296-1996. Dzieje miasta i gminy, Opole 1996.

Damrot Konstanty, Die älteren Ortsnamen Schlesiens, ihre Entstehung und Bedeutung: mit einem Anhange über die schlesisch-polnischen Personennamen: Beiträge zur schlesischen Geschichte und Volkskunde, Beuthen 1896.

Dembska Anna Renata, O testamencie polskim w polskim prawie średniowiecznym. Studia z historii ustroju i prawa. Księga dedykowana Profesorowi Jerzemu Walachowiczowi, pod red. Heleny Olszewskiej, „Prace Wydziału Prawa i Administracji Uniwersytetu im. A. Mickiewicza w Poznaniu", 7 (2002) s. 70-97.

Dziewulski Wojciech, Przeszłość Baborowa (do r. 1945), „Kwartalnik Opolski”, 3 (1958) s. 67-79.

Gieraths Georg, Peregrinus, OP, Predigtschriftsteller, w: Lexikon für Theologie und Kirche, t. 8, Freiburg 1986, k. 270.

Gottschalk Joseph, Euphemia von Ratibor (†1359).Untersuchung der Quellen zu ihrer Lebensgeschichte, „Archiv für schlesische Kirchengeschichte“, 1 (1936) s. 15-40.

Gromann Carl, Nachrichten über Ratibor, w: „Allgemeiner Anzeiger des Oberschlesischen Patriotischen Instituts für Landwirthe, Kaufleute, Fabrikanten und Künstler”, 1 (1810) nr 86, s. 454-455.

Halmer Damian, Kilka uwag o lokalizacji i powstaniu miasta Baborów, w: Europa, Śląsk, Świat najmniejszy, red. Hanna Honysz, Janusz Mokrosza, Katowice-Rybnik 2007, s. 86.

Hyckel Georg, Die gottselige Euphemia von Ratibor, „Taubstummen-Führer”, 35 (1930) nr 11, s. 77.

Kałuża Henryk, Korona albo krzyż..., Racibórz 2015.

Kłodziński Adam, Anna, w: Polski Słownik Biograficzny, t. 1, Kraków 1935, s. 119.

Kublin Grzegorz, Eufemia raciborska - priorissa, „Studia Teologiczno-Historyczne Śląska Opolskiego", 32 (2012) s. 287-294.

Kublin Grzegorz, Sprawa zagubienia się pieniędzy Eufemii, „Studia Teologiczno-Historyczne Śląska Opolskiego", 30 (2010) s. 493-499.

Kublin Grzegorz, Niedrukowany dokument z 1 maja 1331 roku dotyczący klasztoru dominikanek w Raciborzu, „Studia Teologiczno-Historyczne Śląska Opolskiego”, 35 (2015) s 335-343.

Kublin Grzegorz, Świątobliwa Eufemia raciborska (†17 I 1359), Opole 2013. 
Kublin Grzegorz, Średniowieczne i nowożytne «testimonia sanctitatis» Eufemii raciborskiej (zm. 1359), „Folia Historica Cracoviensia”, 19 (2013) s. 77-83.

Kublin Grzegorz, XVII-wieczny żywot księżniczki raciborskiej Eufemii w zbiorach Archiwum Państwowego we Wrocławiu, Opole 2016.

Kwiatkowska Cecylia, Klasztor Dominikanek w Raciborzu, Rep. 112, w: Archiwum Państwowe we Wrocławiu. Przewodnik po zasobie archiwalnym do 1945 roku, red. Andrzej Dereń, Rościsław Żerelik, Wrocław 1996, s. 291-292.

Linge Carl, Denkwürdigkeiten Oberschlesiens, cz. 3, Ratibor 1824, s. 3-10.

Linge Carl, Schulschriften, Breslau 1828, s. 109-122.

Lompa Józef, Krótki rys jeografii Śląska dla nauki początkowej, Głogówek 1847.

Madro Stanisław, Euphemia v. Ratibor, w: Lexikon für Theologie und Kirche, t. 3, Freiburg 1995, szp. 992.

Mika Norbert, Dzieje ziemi raciborskiej, Kraków 2012.

Mika Norbert, Eufemia (Ofka), w: Raciborzanie tysiąclecia. Słownik biograficzny, Racibórz 2002, s. 32-33.

Mika Norbert, Bělastová Šarka, Racibórz-Opava. Podręcznik do edukacji regionalnej. Př́ručka k regionální výuce, Racibórz-Opava 2010, s. 94-97.

Mrówczyński Jerzy, Polscy kandydaci do chwały ołtarzy, Wrocław 1987.

Nerlich Elisabeth, Aus der Geschichte der Stadt Sohrau OS, Dortmund 1972.

Newerla Paweł, Dzieje Raciborza i jego dzielnic, Racibórz 2008.

Newerla Paweł, Opowieści o dawnym Raciborzu, Racibórz 1996.

Niezgoda Cecylian, Błogosławiona Salomea Piastówna, Kraków 1996.

Nowack Anton, Die Stadtpfarrkirche zum heiligen Philippus und Jacobus in Sohrau O/S, Neustadt OS 1900.

Pater Jan, Święci w dziejach Śląska, Wrocław 1997, s. 32-34.

Plebankiewicz Wojciech, Eufemija Domicella, „Przyjaciel Ludu”, 9 (1842) nr 12, s. 95 96.

Porwoł Paweł, Kaplica Polska (1-2), „Nowiny Raciborskie”, 5 (1996) nr 29-30, s. 8.

Porwoł Paweł, Kaplica św. Dominika (1-2), „Nowiny Raciborskie”, 5 (1996) nr 27-28, s. 8.

Porwoł Paweł, Zagadkowy obraz świątobliwej Eufemii (1-5), „Nowiny. Tygodnik ziemi rybnickiej, wodzisławskiej i raciborskiej”, 36 (1995) s. 7, 38, 40-42.

Prus Konstanty, Świątobliwa Ofka Piastówna i klasztor ss. dominikanek w Raciborzu, Opole 1948.

Schaffer Hermann, Geschichte einerschlesischen Liebfrauengilde seit dem Jahre 1343. Ein Beitrag zu der Geschichte der Gilden und religiösen Bruderschaften. Nach Urkunden und handschriftlichen Quellen verfaßt, Ratibor 1883.

Seppelt Franz Xaver, Die Breslauer Diözesansynode vom Jahre 1446, Breslau 1912.

Snoch Bogdan, Górnośląski leksykon biograficzny, Katowice 1997.

Solicki Stanisław, Leszek (Leszko), w: Polski Słownik Biograficzny, t. 17, Wrocław 1972, s. 161.

Sossalla Józef, Sylwetka świątobliwej Ofki, „Wiadomości Urzędowe Kurii Biskupiej Śląska Opolskiego", 27 (1972) nr 2, s. 57-60.

Stefaniak Piotr, Błogosławiona Eufemia Piastówna OP (1299-1359) w świetle trzech najstarszych żywotów oraz źródeł a także literatury, „Nasza Przeszłość”, 111 (2009) s. $159-191$.

Stefaniak Piotr, Błogosławione dominikanki; Ofka Piastówna (1299-1359) i Elżbieta Węgierska (1292-1336) - środkowoeuropejskie wzorce świętości z XIV wieku, „Studia Teologiczno-Historyczne Śląska Opolskiego", 35 (2015) s. 292-333. 
Stefaniak Piotr, Dzieje dominikanek raciborskich. Studia na jubileusz 700-lecia fundacji klasztoru Świętego Ducha w Raciborzu i 800-lecia założenia mniszek Zakonu Kaznodziejskiego, Racibórz 2006.

Stefaniak Piotr, Eufemia Domicylla Piastówna, zwana błogosławioną (1299-1359), „List do Pani", 12/120 [200], (2012), s. 32.

Stefaniak Piotr, Ikonografia świątobliwej Ofki Piastówny, Wrocław 2015.

Stefaniak Piotr, Mistyczki. Święte i błogosławione mniszki dominikańskie, Racibórz 2007, s. 44-48

Stefaniak Piotr, Raciborska przeorysza Eufemia Domicylla Piastówna (1299-1359), „Miejsca Święte”, 8 (127), 2007, s. 16.

Stefaniak Piotr, Z dziejów relikwii świątobliwej Ofki Piastówny, dominikanki raciborskiej, „Śląskie Studia Historyczno-Teologiczne”, 44 (2011) z. 1, s. 45-58.

Suchoń Benigna, Ofka, Eufemia, Domitilla, w: Hagiografia polska. Słownik bio-bibliograficzny, t. 2, red. Romuald Gustaw, Poznań 1972, s. 160-171.

Szymański Andrzej, Świątobliwa Eufemia (Ofka) raciborska - księżna i dominikanka, „Studia Śląskie”, 64: (2005) s. 217-230.

Tschauder Anton, Kurze Geschichte der Stadt Bauerwitz, Leobschütz 1881.

Wawoczny Grzegorz, Miejsca święte ziemi raciborskiej, Racibórz 2001.

Wawoczny Grzegorz, Świątobliwa Ofka Piastówna, w: Dzieje parafii Wniebowzięcia Najświętszej Maryi Panny w Raciborzu, red. G. Wawoczny, Racibórz 2005, s. 181-194.

Wawoczny Grzegorz, Zabytki powiatu raciborskiego, Racibórz 2007.

Weltzel Augustin, Geschichte der Stadt Ratibor, Ratibor 1861.

Weltzel Augustin, Geschichte der Stadt und Herrschaft Ratibor, Ratibor 1881.

Weltzel Augustin, Żywot Błogosławionej Eufemii, „Towarzystwo Bożego Grobu”, 11 (1878) z. 22, s. 477-492.

Wilms Hieronymus, Geschichte der deutschen Dominikanerinnen 1206-1916, Dülmen 1920, s. 122-123.

Wolnik Franciszek, Sekularyzacja raciborskich klasztorów dominikańskich, w: Sekularyzacja dóbr kościelnych na Górnym Śląsku w 1810 roku, pod red. Franciszka Wolnika, Opole 2011.

Wolnik Franciszek, Świątobliwa Eufemia (Ofka) - życie i rozwój jej kultu, w: Świętość na ziemi raciborskiej. Materiały z sesji naukowej zorganizowanej w dniu 16 stycznia 2009 przez Urząd Miejski w Raciborzu, Parafię Wniebowzięcia NMP w Raciborzu oraz Katedrę Historii Kościoła i Patrologii Wydziału Teologicznego Uniwersytetu Opolskiego w Muzeum Miejskim w Raciborzu, z okazji 650. rocznicy śmierci świątobliwej Eufemii (Ofki), red. Franciszek Wolnik, Opole 2009, s. 23-43.

Wolny Jerzy, Łaciński zbiór kazań Peregryna z Opola i ich związek z tzw. «Kazaniami Gnieźnieńskimi», w: Średniowiecze. Szkice o kulturze, t. 1, red. Julian Lewański, Warszawa 1961, s.171-238.

Wolny Jerzy, Peregryn z Opola, w: Polski Słownik Biograficzny, t.25, Wrocław 1980, s.598-602.

Woroniecki Jacek, Eufemia raciborska, w: Polski Słownik Biograficzny, t. 4, pod red. Władysława Konopczyńskiego, Kraków 1948, s. 318-319.

Wolný Gregor, Kirchliche Topographie von Mähren, t 5. Brünn 1863.

Zdanek Maciej, Fragment akt kapituły prowincjalnej dominikanów polskich z 1338 r., „Roczniki Historyczne”, 76 (2010) s. 271.

Żebrawski Teofil, O pieczęciach dawnej Polski i Litwy, Kraków 1865. 


\title{
OFKA PIASTÓWNA'S WILL OF 1358, A PRIORESS OF THE RACIBÓRZ DOMINICAN NUNS
}

\begin{abstract}
Summary
On 8 December 1258, an almost sixty-year-old prioress of the Racibórz Dominican Nuns, Ofka Piastówna, made a will before a notary public, Piotr Gotfridi, a presbyter of Wrocław. It is one of the two known legal documents of this type from the Middle Ages, which were produced by a nun coming from a noble family living on Polish soil. On this occasion the Dominican monastery in Racibórz hosted the notables from the local duke's court, including Mikołaj II Przemyślida, representatives of the knighthood, the burghers and the authorities of the Polish Dominican Province. In her will, Ofka secured the economic prosperity of the monastery, which was headed by her, and founded by her father, Duke Przemyslaw Piastowicz. The will which was prepared in Latin in two similar versions was held by the Racibórz Dominican Nuns in the archives to the moment of the dissolution of their monastery ordered by Frederick William III on 30 October 1810. Then, together with other documents, it was finally stored in the State Archives in Wrocław, where it was destroyed or stolen at the end of the war in 1945. Now we know this document from the CodexdiplomaticusSilesiae edition.
\end{abstract}

Keywords: Ofka Piastówna; a will; a prioress; the Dominican Nuns; Racibórz 